\title{
HOMERO NOS POETAS LÍRICOS: RECEPÇÃO E TRANSMISSÃO ${ }^{1}$
}

\author{
Adrian Kelly* * Tutorial Fellow \\ nec dubitari debet quin fuerint ante Homerum poetae. \\ Cícero, Brutus, 71 \\ Não há Virgílios aqui. \\ Fowler $(1985,39)$ \\ in Ancient Greek \\ Language and \\ Literature no Balliol \\ College, Oxford, e \\ Clarendon University \\ Lecturer in Classics \\ na Universidade de \\ Oxford.
}

\begin{abstract}
RESUMO: A pesquisa acadêmica sobre Homero está crescentemente inclinada a usar um modelo estematológico para explicar a relação do poeta com seus predecessores, sejam gregos ou não gregos: isto é, Homero aparentemente usou poemas escritos e fixos na maneira alusiva de Calímaco ou Virgílio. Todavia, à parte seus profundos problemas metodológicos, essa concepção da cultura poética grega não encontra paralelo ou apoio na recepção de Homero nos poetas líricos arcaicos gregos mais antigos: não há nestes uma boa evidência de uma cultura literária altamente alusiva até a metade do séc. VI a.C., na poesia de Estesícoro, cuja obra representa uma clara mudança no modo como os textos homéricos são conhecidos, recebidos e recriados. 'Não há Virgílios’ na Grécia arcaica, e a concepção não tem lugar na história da literatura grega mais antiga.
\end{abstract}

PALAVRAS-CHAVE: Homero; Estesícoro; intertextualidade.

\section{HOMER IN THE LYRIC POETS: RECEPTION AND TRANSMISSION}

\begin{abstract}
Homeric scholarship is increasingly inclined to use a stemmatological model to explain the poet's relationship to his forebears, whether Greek or non-Greek: that is, Homer apparently used written and

\footnotetext{
${ }^{1}$ Gostaria de agradecer a Antonio Orlando Dourado-Lopes e a Teodoro Assunção por seu convite para a apresentação, na qual se baseia este artigo, na XI Semana de Pós-Graduação em Estudos Clássicos da FALE-UFMG: Reinterpretando Homero, realizada na Faculdade de Letras da UFMG, em 9/11/2012, e por sua generosidade e hospitalidade durante minha estadia. Também gostaria de agradecer a Felix Budelmann, Patrick Finglass, Barbara Graziosi, Henry Spelman e Martin West pela discussão deste material, e a Patrick Finglass e Malcolm Davies por uma visão antecipada de seu comentário inédito sobre Estesícoro. Uma versão mais longa e em língua inglesa deste artigo figura com o título “Stesichorus' Homer" em Finglass; Kelly, 2015, p. 21-44.
} 
fixed poems in the allusive manner of Callimachus or Virgil. However, aside from its profound methodological problems, this conception of Greek poetic culture finds no parallel or support in the reception of Homer in the early Greek lyric poets: there is no good evidence there for a highly allusive literary culture until the middle of the 6th century BC, in the poetry of Stesichorus, whose work represents a clear shift in the way Homer's texts are known, received and recreated. 'There are no Virgils' in Archaic Greece, and the conception has no place in the history of early Greek literature.

KEYWORDS: Homer; Stesichorus; intertextuality.

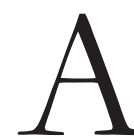

recepção mais antiga de Homero é um assunto importante mais uma vez, na medida em que olhos acadêmicos retornam de um modo algo ávido à "Questão Homérica", à origem da Ilíada e da Odisseia. Após décadas de consenso, nas quais foi reconhecido que a existência de uma tradição oral deveria oferecer algum tipo de verificação para reconstruções confiantes das "fontes" de Homero, ${ }^{2}$ agora os críticos estão crescentemente usando um modelo muito letrado e textualizado para falar de poesia nesse período: isto é, não somente Homero estava ciente e servindo-se de poemas épicos relativamente fixos, como estava também "interagindo" com uma variedade de textos do "Oriente Próximo". ${ }^{3}$ Há muitas razões para se resistir a essa certeza recentemente descoberta sobre os antepassados de Homero, mas uma que não foi examinada adequadamente nesse contexto é a vasta incerteza acerca da recepção poética e da transmissão da poesia homérica no período arcaico. Se, em outras palavras, o próprio Homero estava trabalhando em uma cultura altamente letrada e alusiva, do tipo rotineiramente atribuído a períodos posteriores da história grega, então deveríamos esperar alguma evidência de que seus poemas eram usados desse modo por seus sucessores mais próximos, os poetas elegíacos e líricos do período arcaico. ${ }^{4}$ Este artigo vai sugerir que é muito difícil achar evidência para esse tipo de recepção.

Para antecipar nossas conclusões com um outro tipo de evidência, lembremo-nos de que representações artísticas de cenas "épicas" nesse período não sustentam o que foi um dia um clichê na Questão Homérica, isto é, que a emergência da Ilíada e da Odisseia, tão claramente superiores ao restante da narrativa heróica mais antiga, foi um momento "big bang" com um impacto imediato na cultura grega. Em vez disso, Robert Cook e Anthony Snodgrass estabeleceram, sem sombra de dúvida, que cenas de outras partes da guerra de Troia continuaram a predominar sobre cenas mais estreitamente "homéricas" até boa parte

\footnotetext{
${ }^{2}$ Cf., inter multa alia, Jensen, 1980, p. 102.

${ }^{3}$ Para exemplos dessas novas direções na pesquisa sobre Homero, cf. Currie, 2001 e 2012; para uma breve crítica, cf. Kelly, 2010, em português e com mais bibliografia.

${ }^{4}$ Para uma discussão introdutória da relação entre Homero e os poetas líricos, cf. Graziosi; Haubold, 2009.
} 
do sexto século a.C. ${ }^{5}$ Apesar de haver (sobretudo) cenas iliádicas representadas do último terço do sétimo século, elas permanecem minoria ao longo do período arcaico. É somente no final desse período que os gregos começam a falar sobre "Homero", e ele permanece nosso terminus ante quem mais certo para a emergência dos seus poemas à luz do conhecimento público na Grécia arcaica. ${ }^{6}$ Todavia, deve ser enfatizado que isso é um terminus: na medida em que os poemas devem ter existido na forma em que os temos antes dessa data, ${ }^{7}$ nós não temos boa evidência de precisamente quando ou onde eles se originaram, e certamente não de sua influência sobre outros artistas do período arcaico.

É a reivindicação central deste artigo que, para uma evidência poética dessa influência, nós tenhamos que esperar por Estesícoro no meio do século VI a.C. Isso porque achamos em seus fragmentos a primeira evidência realmente sólida de um engajamento permanente, "intertextual" com a epopeia homérica. Estesícoro pode não ser o primeiro poeta a ter conhecido, utilizado ou aludido a Homero, uma vez que a evidência é na maior parte ínfima demais, fragmentária demais para que tenhamos certeza. Ele é, entretanto, o primeiro poeta de quem podemos dizer com segurança que almejou que sua audiência reconhecesse a interação homérica nos seus próprios textos como algo mais do que apenas um repositório de episódios famosos, ou um apelo generalizado à autoridade e ao status de Homero, mas como um texto interpretado, inteiro. Andrew Ford sustentou que Heródoto é o primeiro grego a mostrar uma tal apreciação permanente de Homero, ${ }^{8}$ mas este artigo se empenhará na apresentação do caso, seguindo a iniciativa de Walter Burkert, ${ }^{9}$ de que deveríamos vê-lo um século antes.

\section{Metodologias de Recepção}

A história da recepção homérica na literatura arcaica é habitualmente explorada no contexto da(s) Questão(-ões) Homérica(s). Assim, um dia esteve muito em voga entre acadêmicos usar a evidência dos poetas líricos do século VII como evidência para a composição da Ilíada e da Odisseia. A constatação de que a cultura grega mais antiga não era letrada, entretanto, há muito tempo começou a gerar múltiplas dúvidas quanto a desenhar

\footnotetext{
${ }^{5}$ Cf. Cook, 1983; Snodgrass, 1998.

${ }^{6}$ Cf. especialmente West, 1999, p. 378: “Quanto ao resto, poetas no século sétimo e na primeira metade do sexto mostram vivo interesse pelo tema de várias epopeias, mas nenhum pelo poeta ou poetas que lhe deram forma... em tudo isso, nenhuma alusão ao poeta Homero. Isso dificilmente pode ser um mero acidente de preservação. Do último terço do século sexto em diante a imagem é flagrantemente diferente. Homero salta para a vida. Autor após autor o nomeia e comenta suas conquistas. As epopeias não são mais tratadas como registros autônomos do passado, mas como criações artísticas de um indivíduo, para serem louvadas ou criticadas.”

${ }^{7}$ Este artigo não interage com a teoria da cristalização da transmissão homérica adotada por Gregory Nagy e seus estudantes; cf. Nagy, 1996, e sua reafirmação em Bird, 2010.

${ }^{8}$ Ford, 1997.

${ }^{9}$ Burkert, 1987.
} 
linhas entre os textos dessa forma. J. A. Davison sustentou certa vez que geralmente citações aceitas de alusões a Homero não eram, de fato, evidência de quaisquer relacionamentos textuais diretos, e Robert Fowler deu uma versão mais comedida do mesmo ponto trinta anos depois. ${ }^{10}$ Seu ceticismo foi influenciado por diversos fatores: dúvidas sobre a extensão de textualização escrita, a abundância de outros poemas ou performances com o mesmo material, a qualidade tradicional e formular não apenas de formas épicas, mas também não-épicas, o fato de que Homero foi originalmente associado a muito mais poemas do que a Ilíada e a Odisseia, e assim por diante. ${ }^{11}$

Com efeito, toda essa caução esforça-se por evitar o erro que foi recentemente denominado OQVVETOQH - O Que Você Vê É Tudo O Que Há - ${ }^{12^{*}}$ uma versão da falácia documental que continua a deixar suas marcas por todas as histórias da literatura grega antiga. ${ }^{13} \mathrm{E}$, claro, uma tentação inteiramente natural - especialmente quando a maior parte das evidências é tão fragmentária - desenhar linhas entre nossos textos que sobreviveram e negligenciar as milhares de linhas e poemas que devem ter existido no período mais antigo. Realmente, por que deveríamos passar tanto tempo pensando em "conhecidos desconhecidos" ou, ainda melhor, os quase-rumsfeldianos "desconhecidos desconhecidos"? Uma das principais razões é que, se não o fizermos, então o processo resultante é altamente subjetivo, e tudo depende de o quão alto ou baixo nós escolhermos colocar a barra probatória em cada caso.

Como nosso primeiro exemplo dos problemas com que se defronta qualquer investigação do presente tipo, peguemos o bem conhecido tema dos "homens como folhas", primeiramente encontrado no canto VI da Ilíada (146-9):

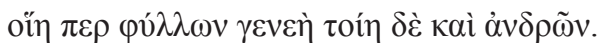

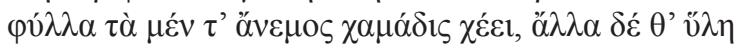

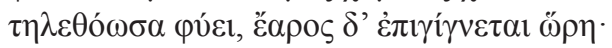

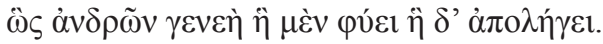

\footnotetext{
${ }^{10}$ Davison, 1955; Fowler, 1987.

${ }^{11}$ Para uma afirmação exemplar nessa direção, cf. Rosenmeyer, 1997, p. 125, embora então, enigmaticamente, ela argumente em favor de imitações diretas de poesia homérica em Safo: "Reconheço que epicismos na poesia arcaica nem sempre precisem indicar um diálogo com Homero. Palavras ou cenas épicas nos poemas líricos de Safo podem ser coincidentes, fórmulas líricas de uma tradição independente, alusões a outros poemas líricos (que tenham ou não sobrevivido) onde ocorrem epicismos, alusões a outros poemas do ciclo épico agora perdidos, ou alusões a versões anteriores ou locais da Iliada e da Odisseia antes de sua regularização textual."

${ }^{12^{*}}$ N. do T.: em inglês a sigla é WYSLATI, correspondente a "What You See Is All There Is".

${ }^{13}$ Para o conceito, originalmente concebido como um meio para explicar escolhas não otimizadas em economia, cf. Kahneman, 2011.
} 
No final do século VI a.C., Simônides fr. $19 \mathrm{~W}^{2}$ cita Ilíada, VI, 146 verbatim, atribuindo-o ao homem cego de Quios, antes de chegar ao ponto de identificá-lo no fr. 20 $\mathrm{W}^{2}$ (recentemente reanexado ao fr. $\left.19 \mathrm{~W}^{2}\right)^{14}$ como 'divino Homero':

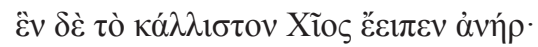

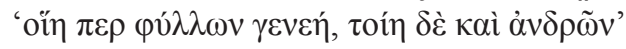

$\ldots$

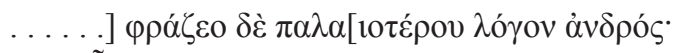

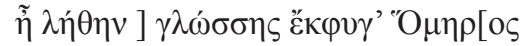

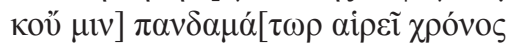

Este é um terminus ante quem sólido como uma rocha para a emergência dos poemas homéricos, e para seu uso tanto por poetas quanto por audiências. Esse fato merece ser enfatizado: não é apenas uma reutilização ou um reenquadramento arbitrários de um outro verso, mas a invocação explícita da criação específica de um outro poeta. Em outras palavras, ela mostra que tanto o nome "Homero" quanto a própria poesia homérica eram suficientemente bem conhecidos e considerados uma autoridade em meio à audiência de Simônides para que o poeta os redesdobrasse dessa forma. ${ }^{15}$

Mas o próprio tema, mesmo tão antigo quanto Homero, é tradicional: ele o desdobra diversas vezes de um modo que mostra que ele não era o primeiro a expressar o pensamento. ${ }^{16}$ Quando, portanto, reaparece em Mimnermo fr. $2 \mathrm{~W}^{2}$, deveríamos empurrar nosso terminus um pouco para trás, para o terceiro terço do século VII a.C.?

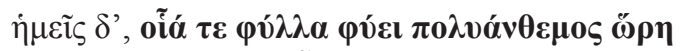

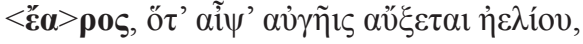

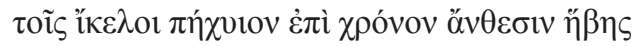

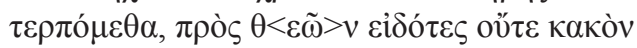

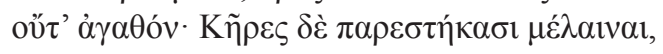

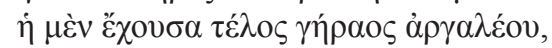

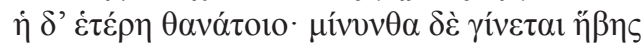

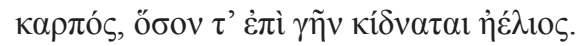

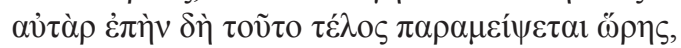

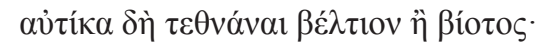

\footnotetext{
${ }^{14}$ Cf. Bowie, 2010, p. 78.

${ }^{15}$ É difícil saber que outro uso (se algum) Simônides estaria fazendo dessa citação no contexto do seu poema, um problema que encontraremos repetidamente.

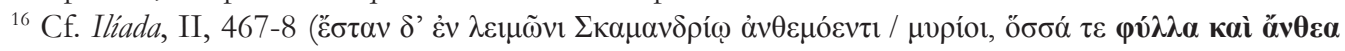

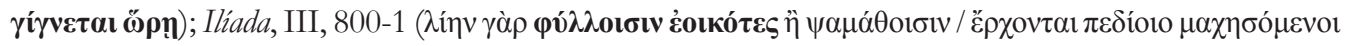

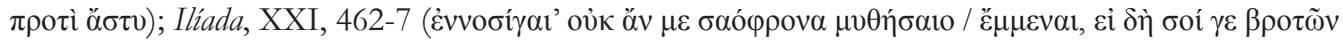

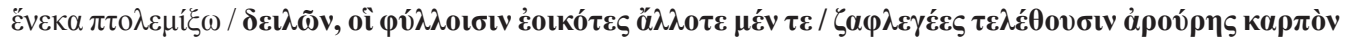

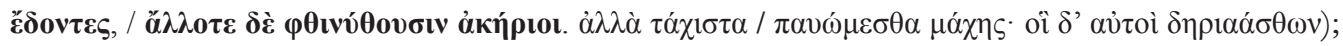

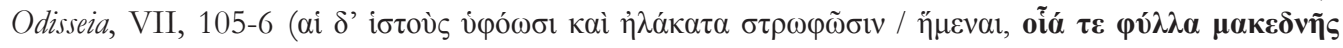

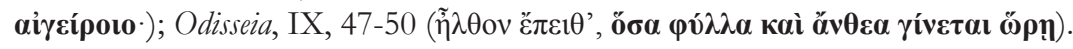


Evidentemente, isso não é uma citação de Homero no mesmo sentido que nos fragmentos de Simônides, porque não há de fato trecho citado ou invocação de uma outra fonte poética, mas poderia ser - em realidade, foi - considerado uma alusão direta e recriativa à passagem homérica. ${ }^{17}$ No entanto, dado o pano de fundo tradicional indicado claramente mesmo em Homero, Fowler e mais recentemente Jonathan Burgess têm com certeza razão de serem céticos quanto a Mimnermo estar fazendo algo além de usar um tema tradicional. ${ }^{18}$ É claro que não podemos ter certeza, já que a própria natureza da alusão e da recriação é tal que débitos específicos são muito difíceis de serem encontrados. Mas em um tal contexto, em que temas tradicionais existem independentemente das poucas representações individuais que sobreviveram, devemos proceder cautelosamente. Sem o tipo de gatilho - falando especulativamente - que encontramos em Simônides fr. $19-20 \mathrm{~W}^{2}$, não pode ser seguro concluir em favor das interações diretas de Mimnermo com Homero.

Todavia, adotemos momentaneamente essa conclusão. O que a interação acrescentaria ao poema de Mimnermo? Colocamos usualmente a questão de uma alusão para identificar algo sobre a história textual de Homero ${ }^{19}$ mas deveríamos também considerar o fenômeno de interação poética de uma perspectiva levemente mais ampla, no que diz respeito ao uso que for feito de Homero. Neste caso, não parece exigir-se que um membro da audiência, ao reconhecer ou lembrar-se da passagem homérica, faça muito com ela, em termos intertextuais ou interpretativos. É de fato muito difícil ver a que propósito mais amplo a alusão poderia servir aqui. Talvez possa haver uma nuance heroica a mais na visão algo pessimista da vida humana de Mimnermo, mas isso não demanda que o membro "alerta" da audiência devesse ativar uma compreensão ou interpretação dessa passagem homérica particular, ou mesmo da poesia homérica em geral, de modo a iluminar a elegia. ${ }^{20}$

Portanto, esse caso serve de modelo para se identificar interações homéricas no período arcaico: primeiro, assegurar - na medida do possível - que a passagem está realmente interagindo com a Ilíada e Odisseia de Homero, em vez de o fazer com um fundo não-específico e genericamente épico; segundo, acessar a interação no que ela pede que a audiência evoque dos poemas homéricos, e como a evocação afeta o poema-alvo. Isso tudo pode parecer bastante autoevidente, claro, sobretudo quando se lida com um corpo de evidência tão bem conhecido. Mas a cautela nesses assuntos parece ter saído recentemente pela janela, já que os pesquisadores imaginam crescentemente um Homero que, aparentemente,

\footnotetext{
${ }^{17}$ Cf. Bowie, 2010, p. 60; Adkins, 1985, p. 99, obiter.

${ }^{18}$ Fowler, 1987, p. 32-3; Burgess, 2001, p. 117-26, 190-1.

${ }^{19}$ Cf. West, 2002, p. 207: “(...) Não estou preocupado aqui com a interpretação dos poetas lésbios ou seu uso do material mítico, mas antes com a tentativa de estabelecer que poesia épica estava disponível para eles." Talvez as duas tarefas tenham que ser vinculadas mais proximamente.

${ }^{20}$ Cf. Fowler, 1987, p. 33: "A questão é se em alguma dessas passagens nós realmente temos que nos lembrar dos detalhes do modelo, de modo a entender o ponto da imitação (sobre Tirteu fr. 2 W) [...]. O objetivo do poeta é evocar de um modo geral a atmosfera heroica de Homero (...), não exatamente a mesma coisa que pedir ao leitor que considere o contexto original e descubra quais aspectos do modelo são relevantes."
} 
seria conhecedor não somente de diversos poemas épicos gregos muito fixos, mas também de um ou dois não-gregos, e que interagiu com eles de um modo muito virgiliano. Deste ponto de vista, cultura e dinâmica letradas irrompem inteiramente formadas no período arcaico, como se esses tipos de interação poética estivessem apenas esperando pelo aparecimento de textos escritos para florescer em sua forma conhecida tardiamente: ninguém teve que pensar sobre ela, nenhuma concepção sobre composição poética, performance ou re-performance tiveram que mudar ou evoluir: elas simplesmente existiam desde o princípio. Eu acho difícil acreditar nessa impetuosa série de prótases notavelmente incertas, e ainda mais difícil incluir nela muita fé analítica, mas deve-se finalmente curvar-se ante o princípio de tot homines, quot sententiae. Entretanto, este artigo espera mostrar que Estesícoro fornecerá o que é necessário para levar o debate adiante, e lançar uma luz muito necessária no processo.

\section{Poesia lírica antes de estesícoro - alCeU, safo, Álcman \& Íbico}

Estesícoro não é, obviamente, o primeiro dos poetas líricos a ter sido ligado aos poemas homéricos ${ }^{21}$ e talvez o candidato individual mais forte para uma tal alusão seja Alceu fr. 44, cuja reivindicação é tão poderosa que até mesmo um cético como Fowler é levado a admitir:22

$\dot{\alpha} \gamma[$
$\ddot{\alpha} \kappa[\ldots \ldots \ldots \ldots \ldots] \cdot[$
$\theta .[\ldots \ldots \ldots \ldots \ldots.] \cdot[$
$\dot{\varepsilon}[\ldots \ldots \ldots \ldots \ldots] .[.] \cdot \rho[..] . .[$

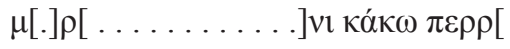

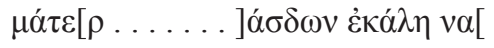

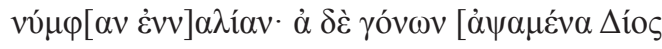

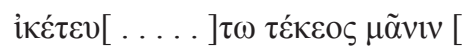

Este artigo nada contra a corrente, não porque fará qualquer diferença particular à tese básica, mas sobretudo para mostrar a subjetividade de uma tal conclusão ou identificação,

\footnotetext{
${ }^{21}$ É claro que a terminologia aqui é difícil (lírica? mélica? não-épica?), e envolve necessariamente algumas exclusões. A primeira delas, por razões de espaço, são os poetas elegíacos / jâmbicos mais antigos, sobre os quais cf. Fowler, 1987 e Burgess, 2001, contra, p. ex., Adkins, 1985 e Bowie, 2010, p. 60-7, 78. Eu uso o texto de Voigt para Safo e Alceu e Poetarum Melicorum Graecorum Fragmenta (PMGF) para Álcman, Íbico e Estesícoro.

${ }^{22}$ Cf. Fowler, 1987, p. 37; também Meyerhoff, 1984, p. 46-53; West, 2002, p. 208-9; Liberman, 1999, i ad loc., p. 38; contra Jensen, 1980, p. 102-3, cujo argumento é muito similar, e Burgess, 2001,

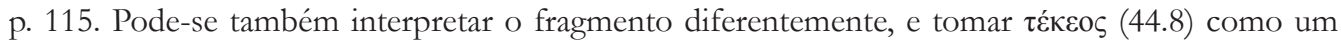

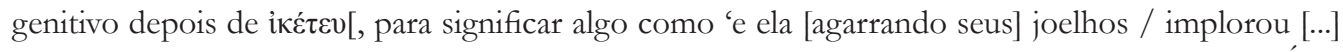
(à) sua criança [abandonar] sua cólera', de algum modo afim com as linhas de Eur. Ifigênia em Áulis,

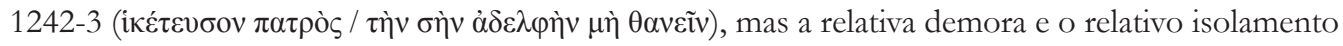
da construção com o genitivo é perceptível.
} 
e o quão prontamente ela pode ser minada. Primeiramente, Aquiles está profundamente inserido no sistema de fórmulas da epopeia homérica: ${ }^{23}$ a Ilíada não foi a primeira ou a única composição sobre ele a ter sido cantada, ou tomando-o como sua peça central. Além do mais, dado seu caráter, é dificilmente impensável que diversas histórias sobre suas dificuldades de administrar a ira, ou o que os oralistas gostam de chamar 'um padrão de história de cólera', estivessem circulando no período mais antigo. ${ }^{24}$ Inter alia plurima, Pátroclo pode falar do seu

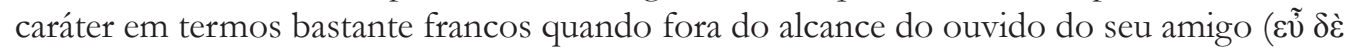

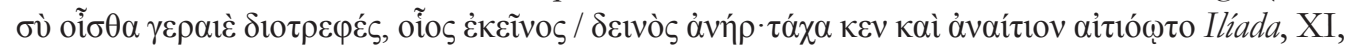
653-4), e a neo-análise sugeriu que um padrão de cólera também estruturou o comportamento de Aquiles na Etiópida (envolvendo sua ira com o assassinato de Tersites: arg. 6-8 B), ${ }^{25}$ mas é uma sequência extremamente comum e variada na poesia homérica, desdobrada (p. ex.) para estruturar o todo da Ilíada ou a lenda de Meleagro na fala de Fênix no canto IX, ou mesmo usada ao longo de uma pequena seção de narrativa de batalha para Eneias no canto XIII, etc. ${ }^{26}$ Não somente popular o suficiente para ser encontrada em outros poemas, mas flexível o suficiente para também aparecer em diversas formas no mesmo poema. ${ }^{27}$ Então, o Aquiles colérico de Alceu não precisa ter sido derivado da nossa Ilíada.

Em segundo lugar, o papel particular de Tétis nos percalços do seu filho são pressupostos em outras epopeias, notadamente na Etiópida (argumento 11, 21-2 B) e em seus antecessores, e Laura Slatkin sugeriu que Homero conhece a história na qual Tétis estava destinada a dar à luz uma criança mais forte do que seu pai, requerendo o seu casamento com um mortal. ${ }^{28}$ Assim, a natureza do favor que Zeus lhe deve no canto I da Iliada (salvando-o

${ }^{23}$ Cf., p. ex., Higbie, 1995 , p. 43-68.

${ }^{24}$ Cf. Lord, 1960, p. 186-97; Kelly, 2007, p. 97-8.

${ }^{25}$ Cf. Burgess, 1997.

${ }^{26} \mathrm{O}$ padrão, tal como exibido no caso de Aquiles, é: 1. Briga (I, 57-305, com Agamêmnon); 2. Retirada colérica [ $\mu \eta v-]$ (I, 306-7, 487ss., permaneceu fora da luta); 3A. Devastação (II, 1 - XVIII, 242, tribulações dos gregos); 3B. Perda pessoal (XVI, 784-867, morte de Pátroclo); 4. Apelo ([i] IX, 174-712, de Fênix, Odisseu e Ájax / [ii] XVI, 784-867 de Pátroclo); 5. Retorno (XIX, 40- XX, 2, ao exército grego, e depois à batalha); 6. Vingança (XX, 41- XXIV, 140, a morte de Heitor). Para outros exemplos, cf. Ilíada, IX, 553-96 (Meleagro): 1. Briga (IX, 553-72, com sua mãe); 2. Retirada colérica [ $\mu \eta v-]$ (IX, 553-4, retirou-se da luta); 3A. Devastação (IX, 573-4, derrota dos calidônios, quase-saque da cidade); 3B. Perda pessoal (IX, 598-9, perda de presentes); 4. Apelo ([i] IX, 574-87, dos mais velhos, Oineu, irmãs, mãe, companheiros / [ii] IX, 588-94, da esposa): também Ilíada, XIII, 460-70ss. (Eneias): 1. Briga (XIII, 460-1, com Príamo); 2. Retirada colérica [ $\mu \eta v-]$ (XIII, 459-60, permaneceu fora da luta); 3A. Devastação / 3B. Perda pessoal (XIII, 427-44, morte de Alcátoo, cunhado); 4. Apelo (XIII, 455-67, de Deífobo); 5. Retorno (XIII, 468-9, avança para combater); 6. Vingança (XIII, 470ss., fracassa na sua tentativa de matar Idomeneu).

${ }^{27}$ Quando Fowler, 1987, p. 37, diz que "poucos acreditarão que uma outra Ilíada de plena extensão (ou mesmo um 'Poema-de-cólera') tenha existido junto com Homero ca. 600 a.C.”, pode-se concordar com a primeira afirmação, mas dificilmente com a segunda.

${ }^{28}$ Slatkin, 1991. 
de uma rebelião divina real) é uma inovação homérica de um outro favor anterior, no qual ela tinha concordado com ou simplesmente sido forçada a casar-se com Peleu. ${ }^{29}$

Essa história original poderia ter sido encontrada em uma narrativa genealógica, mas favores do passado são evocados frequentemente na epopeia grega antiga quando eles estão sendo relembrados no processo de súplica / pedido. ${ }^{30} \mathrm{E}$, portanto, possível que alguma versão anterior do seu relacionamento com Zeus fosse invocada em (no contexto de) ${ }^{31}$ um pedido a ele feito por Tétis. Mesmo o detalhe da súplica no fragmento de Alceu, consequentemente, não precisa ser derivado da nossa Ilíada. De fato, Tétis estava constantemente aproximandose de Zeus em prol do seu filho: em todo caso, nossa Ilíada se refere a uma corrente de informação bastante contínua entre eles (cf., p. ex., Ilíada, XI, 794-5), e os paralelos entre Aquiles e Mêmnon, cuja mãe Éos obtém um favor especial de imortalidade da parte de Zeus (Etiópida, argumento 14-15 B), levaram Wolfgang Schadewaldt a propor um episódio específico no final da Etiópida, no qual, semelhantemente, Tétis pediu a Zeus pela imortalidade que ela adquire para Aquiles. ${ }^{32}$ Dado o tamanho do ciúme com o qual Zeus guarda a fronteira divino / mortal no mito grego antigo, um tal episódio é certamente necessário para se dar sentido ao eventual destino de Aquiles. Assim, o fr. 44 de Alceu poderia ser uma referência à história muito similar à que foi posteriormente conservada, por exemplo, na Etiópida.

Nada disso serve realmente para provar que houve uma outra história ou poema assim, para que a eles aludisse Alceu, e existe uma boa chance de que esse fragmento seja uma referência à Ilíada. Mas os restos da epopeia grega antiga e do que podemos razoavelmente supor hipoteticamente acerca do que perdemos sugerem que, em termos de argumento e evidência, não podemos ter certeza. Consequentemente, o fr. 44 não é uma evidência conclusiva de que Alceu conheceu ou estivesse aludindo aqui à Ilíada. ${ }^{33}$

Isso pode parecer a cada leitor um ceticismo excessivo ou mesmo maldoso, e talvez o seja, ambos ou tudo isso, mas ele serve a um propósito importante e ilustrativo: se se quer evitar OQVVETOQH no processo de identificar a interação homérica, então toda evidência deve ser examinada com um respeito saudável pelas incertezas inerentes à reconstrução da cultura poética da Grécia arcaica. Mas, como observamos acima com o símile dos "homens como folhas" do canto VI da Ilíada, isso é apenas o primeiro passo. Uma vez que o caso foi examinado, precisamos perguntar sobre cada item o que a interação acrescenta à suposta

\footnotetext{
${ }^{29}$ Cf. Willcock, 1962; Braswell, 1971; Slatkin, 1991.

${ }^{30}$ Essa seção da prece é normalmente chamada "bypómnèsis"; cf. Ilíada, I, 39-41, VIII, 240-1 etc.; também Latacz et al., 2000 ad Ilíada, I, 37-42, 40.

${ }^{31} \mathrm{Nem}$ sempre se lembra que Aquiles menciona a história de Briareu quando fala com a sua mãe (Ilíada, I, 396-406), mas Tétis somente se refere em termos gerais a esse benefício quando ela está falando com Zeus (Ilíada, I, 503-4).

${ }^{32}$ Schadewaldt, 1965, p. 160.

${ }^{33}$ Cf. a atitude muito semelhante de Steinrück, 1999, p. 140, a propósito da defesa de Rissman, 1983, p. 9-11, de uma conexão entre Safo fr. 1 e Ilíada, V, 311ss: "Esse contexto não exclui que, como diz Rissman, Safo já aluda de modo bastante polêmico ao canto V da Ilíada com sua canção, mas, no campo metódico, essa interpretação não se oferece como uma relação convincente entre Safo e a Ilíada."
} 
relação. Claro, o problema com o fr. 44 é que o começo do poema está perdido, e assim é muito difícil especular precisamente sobre o que está sendo feito com a referência iliádica. O que podemos dizer, no entanto, é que o conhecimento da Ilíada mostrado aqui é bastante elementar: a súplica de Aquiles à sua mãe, e depois a dela a Zeus, são dois espisódios de destaque, bastante cruciais, no começo da narrativa, envolvendo os personagens principais e o pretexto do poema. Pode-se requerer da audiência que saiba da existência e da trama básica do poema, mas é muito difícil vê-los sendo solicitados a evocar muito da Ilíada em termos dos seus detalhes ou mesmo do seu curso. Claro, o estado exíguo do fragmento deveria ser lembrado, e Alceu pode estar fazendo algo muito sofisticado aqui; apenas não conseguimos dizer que ele é (sofisticado), ou - se ele é - o que está fazendo.

Isso pode ser considerado acima de tudo um problema de evidência ou, antes, do mau estado da sua preservação, ${ }^{34}$ mas considerações genéricas também devem entrar em jogo. Uma interação épica nos poetas líricos é concebida naturalmente dentro das necessidades e do objetivo da composição lírica, portanto restrita em escala, e usualmente ligada a um lugar e a um tempo no presente do autor. ${ }^{35}$ Parcialmente porque a interação desses fatores é tão esporádica, restrita e extremamente alusiva, é difícil identificar um engajamento especificamente com a Ilíada e a Odisseia homéricas. Entretanto, quando interações são sugeridas, nós veremos mais uma vez que não se está pedindo da audiência que faça muita coisa com isso: a sofisticação alusiva de épocas posteriores ainda precisa aparecer, ou ao menos fornecer evidência sem controvérsia do seu aparecimento. Isso pode ser menos uma questão de habilidade do que de desejo, claro, mas devemos proceder muito cautelosamente ao projetar práticas textuais e relações poéticas de um período posterior em um mais antigo.

Por exemplo, Alceu fr. 140.2-7 contém uma lista de armamentos que foi considerada uma citação de Homero ou 'da epopeia': ${ }^{36}$

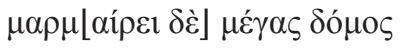

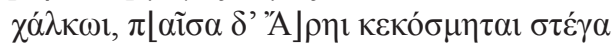

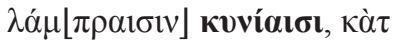

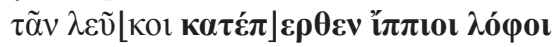

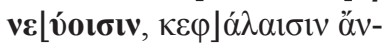

$$
\begin{aligned}
& \delta \rho \omega v \dot{\alpha} \gamma \alpha \dot{\alpha} \mid \lambda \mu \alpha \tau \alpha \text {. }
\end{aligned}
$$

É claro que cenas de armamento abundam em Homero, e os versos 4-5 parecem-se muito com um verso formular (Ilíada, III, 336-7 [Páris] = XI, 41-2 [Agamêmnon] = XVI, 137-8 [Pátroclo] $=$ XV, 480-1 [Teucro]):

\footnotetext{
${ }^{34}$ É interessante observar que o Estesícoro que, semelhantemente, chegou até nós em quantidade exígua fornece muito mais prova de interação homérica direta, e de um modo muito mais claro, o que sugere uma outra interpretação.

${ }^{35}$ Como Graziosi, Haubold, 2009, p. 102 e 100ss., observam, "geralmente, então, parece que a linguagem da lírica é mais situacional do que a da épica."

${ }^{36}$ Page, 1955, p. 209-23; cf. também Rösler, 1980, p. 153-254.
} 


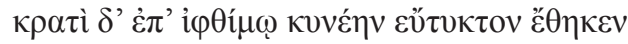

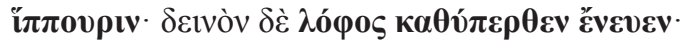

De fato, a linguagem é próxima, mas será que podemos ter certeza de que é à Ilíada que se faz referência? Este é, no final das contas, um verso formular, um elemento dentro de uma cena muito comum e muito típica, e portanto presumivelmente não limitada à nossa Ilíada na experiência de uma audiência arcaica. Mas, à parte um ceticismo desse tipo, se é uma reminiscência homérica, está Alceu pedindo à sua audiência que pense em Páris, Agamêmnon, Pátroclo ou Teucro? Ou há aqui somente uma conotação generalizada do esforço heroico épico, a ser aplicada à circunstância corrente do poeta (especialmente v. 14-5)? ${ }^{37}$ Em qualquer um desses casos, parece haver pouca interação sustentada ou ativa com qual(/is)quer passagem(/ns) homérica(s).

Temas típicos, estruturas narrativas ou dicção não são as únicas barreiras tradicionais identificando uma alusão homérica direta. Tome-se a história de Helena em Alceu fr. 42 e 283, e Safo fr. 16, uma história que foi contada nos (atestados posteriormente) Cípria. ${ }^{38}$ Embora a data desse poema "cíclico" seja desconhecida, o material no qual se baseia era claramente ao menos tão antigo quanto Homero, de modo que seus episódios devem ter sido conhecidos em alguma forma épica mais direta pelos poetas lésbios. O mesmo deve ser dito para o famoso 'Alceu de Colônia' (fr. 298), que conta a história do estupro de Cassandra mais extensamente do que nossas outras composições líricas, mas desta vez comparando a violência de Ájax nessa cena, aparentemente, com o comportamento de Pítaco. ${ }^{39}$ Há muito

\footnotetext{
${ }^{37}$ Assim Rösler, 1980, p. 154. Ver agora Spelman, 2015.

${ }^{38}$ Cf. Meyerhoff, 1984, p. 91-113, fr. 42 (76-86), fr. 283, (54-75), Safo fr. 16; cf. também Rosenmeyer, 1997, p. 125, a respeito de Safo fr. 16 V: “Como podemos não imaginar as consequências, tal como Homero contou a bistória, de como Helena finalmente velejará de volta com o marido que ela está em vias de abandonar? O próprio nome de Helena funciona como uma alusão à epopeia de Homero." Continuando nessa veia, Blondell, 2010, tenta ligar esses poemas (e outros) a Homero, mas não consegue reconhecer a existência de qualquer questão metodológica (contentando-se meramente em citar Rosenmeyer), elide Homero e a 'tradição épica' constantemente, e identifica alusões nos lugares mais tênuos. Por exemplo, ela argumenta que a referência aos cavalos de Aquiles em Alceu fr. 42.14 como $\xi \alpha ́ v \theta \alpha v(. .$. $\pi \omega \dot{\lambda} \omega \nu$ deve referir-se à profecia feita pelo cavalo de Aquiles, Xanto, em Ilíada XIX. Mas, como a própria Blondell nota, "os famosos cavalos de Aquiles [são] mencionados diversas vezes na Ilíada," então presumivelmente esse time imortal era famoso antes de Homero; cf. muito recentemente Schein, 2002, p. 202-4. Depois ela sugere que ỏ $\mu \varphi$ ” $E[\lambda \varepsilon ́ v \alpha r$ (fr. 42.15) é “uma outra alusão homérica” (359),

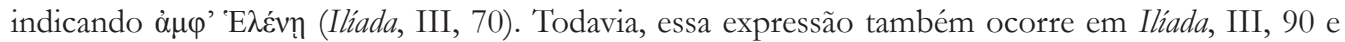
Odisseia, XXII, 227 na mesma posição métrica (e contexto temático), tornando-a assim certamente formulaica. Todas essas poderiam ser ainda alusões a Homero, claro, mas a natureza da evidência deveria gerar maior caução do que nem Rosenmeyer nem Blondell mostram.

${ }^{39}$ Cf. Liberman, 1999, ii p. 99, para bibliografia. Semelhantemente com o nascimento de Aquiles em Alceu fr. 42 (contra Blondell, 2010; cf. n. 37 supra) e Ájax em Alceu fr. 387 (mencionado abaixo, p. 142). O exemplo anterior relaciona material não contido em parte alguma dos poemas homéricos, enquanto o segundo reflete claramente uma duradoura tradição sobre Ájax.
} 
tempo os especialistas chamaram a atenção para a importância da influência épica na poesia lésbia, e por que nesses casos deveríamos pensar em uma interação particular com Homero, por oposição ao material que agora chamamos de "cíclico", é muito pouco claro. ${ }^{40}$ Tanto quanto posso ver, não há nada nesses poemas que anuncie uma filiação ou interação com o próprio Homero por oposição ao épico em geral.

Em relação a isso, Safo fr. 44 ("o poema mais homérico de Safo"41) é particularmente interessante, uma vez que o casamento de Heitor e Andrômaca não é conhecido de outro poema épico, embora não seja difícil vê-lo no interior do âmbito de interesse da narrativa dos Cípria. ${ }^{42}$ Pesquisadores modernos argumentaram que Safo recompõe diversas cenas iliádicas, amplamente dos cantos VI, XXII e XXIV, e note-se uma vez mais que se trata de episódios de destaque - em uma nova história. ${ }^{43}$ Entretanto, nem Heitor nem Andrômaca são invenções homéricas; com certeza, sua tradicionalidade não demanda nenhum argumento, e tem uma história de fundo consistente no poema que indica que ela não é nenhuma invenção homérica, ${ }^{44}$ enquanto ambos os episódios iliádicos que dão a maior parte da informação requisitada - a lamentação prospectiva no canto VI, e a lamentação formal no canto XXIV - são cenas inteiramente típicas. ${ }^{45}$ Por conseguinte, é improvável que Homero tenha sido o primeiro ou o último poeta épico a lembrar as audiências do seu casamento em passagens desse tipo. Além dessas semelhanças de história, não há nenhum gatilho de interação, por exemplo, na forma de uma reminiscência ou expressão que não pudesse ser uma coincidência, resultado de um contexto temático e mitológico compartilhado. ${ }^{46}$ Ninguém negaria que Safo

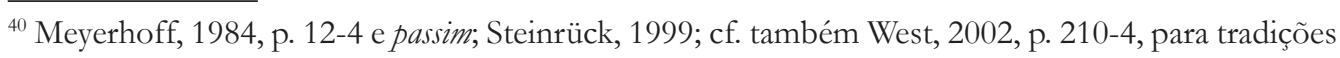
épicas eólicas.

${ }^{41}$ Rissman, 1983, p. 121.

${ }^{42}$ Cf. Apolodoro 3.154 (e os capítulos circundantes para informação similar).

${ }^{43}$ Cf. Rissman, 1983, p. 119-41; Meyerhoff, 1984, p. 118-39; Schrenk, 1994; Bowie, 2010, p. 71-4; contra Suárez de la Torre, 2008. O limite de espaço me impede de tratar em detalhe uma outra relação amplamente proposta entre Safo, desta vez no fr. 1, e diversas (!) cenas em Homero, notadamente o diálogo Afrodite / Helena no canto III da Ilíada, e o diálogo Atena / Diomedes no canto V; cf. Blondell, 2010, p. 373-7, para discussão e mais bibliografia. Basta dizer que preces de um mortal a uma divindade são muito comuns, assim como o são diálogos entre mortais e seus apoiadores divinos, mesmo nos exíguos vestígios da epopeia grega. Além desses paralelos gerais, não há indicação específica de um relacionamento mais direto com uma cena particular; cf. também Hutchinson, 2001, p. 149: “a relação com Homero é comumente considerada agora crucial... essa abordagem concentra-se demais em algumas partes de Homero, e na própria forma da prece, que mesmo na literatura remanescente não está limitada a guerreiros" (grifo meu).

${ }^{44}$ Cf. Wathelet, 1988, p. 274-83, §33.

${ }^{45}$ Cf. Kelly, 2012, para bibliografia e discussão (em português em Kelly, 2010).

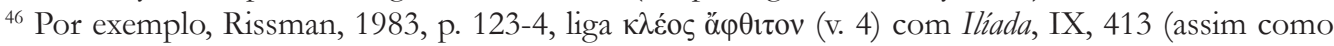
faz Íbico S 151.47; cf. abaixo, n. 77), mas essa é uma expressão tradicional (como nota Rissman, mas a abandona por causa das outras reminiscências homéricas no poema). Além disso, Rissman, 1983, p. 126-7 e Bowie, 2010, p. 72-3, salientam o papel de Ideu (v. 3) como uma alusão ao seu papel no resgate do canto XXIV da Ilíada, todavia Ideu é 'proeminente' em outra parte do poema, tal como
} 
está deliberadamente remetendo à linguagem épica aqui; apenas que não podemos identificar com segurança essas interações como especificamente homéricas na origem.

Ao menos um pouco mais promissora é a descrição do estreitamento das águas de

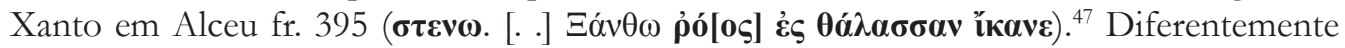
do exemplo prévio, há um episódio na Ilíada que isso poderia refletir, no qual Xanto / Escamandro é estreitado ou sufocado com cadáveres e impedido de fluir para o mar (Ilíada, XXI, 219-20):

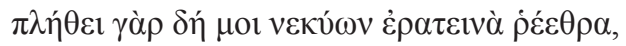

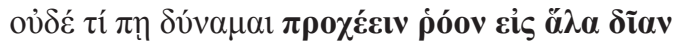

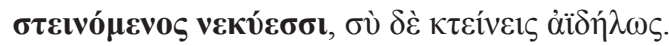

Lembremo-nos de que a batalha na planície - no limite da qual situa-se o rio - é certamente uma característica típica da epopeia da guerra de Troia, e o alvoroço de Aquiles antes da sua morte, preservado posteriormente na Etiópida, pode ser uma fonte para a imagem. Lembre-se também que Xanto / Escamandro tem dois nomes e um sistema formular muito desenvolvido na Ilíada que - como no caso acima de Aquiles - nos mostra que Homero não foi o primeiro ou único poeta épico grego a lhe dar um lugar proeminente na narrativa heroica. ${ }^{48}$ À parte a frequente recorrência em um número de contextos tanto do Oriente Próximo quanto do âmbito indo-europeu, ${ }^{49} \mathrm{O}$ tema também é encontrado na nova 'elegia de Télefo' de Arquíloco, na qual o rio Caico é estreitado com os cadáveres dos heróis gregos em fuga diante de Télefo (v. 8-10): ${ }^{50}$

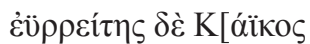

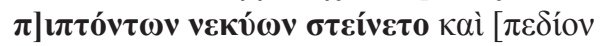

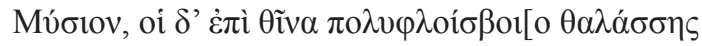

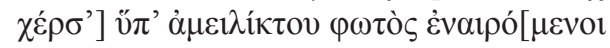

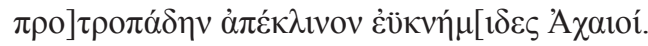

Dado este pano de fundo, não podemos concluir que o uso do tema por Alceu precisa estar se referindo à descrição de Xanto de Homero. Mesmo se pudéssemos chegar a tal conclusão, é claro que não podemos especular sobre o propósito, extensão ou tipo de interação, por causa do estado do fragmento.

na Teikhoskopía, onde ele convoca Príamo para o campo de batalha, ou ao interromper o duelo no canto VIII e depois participar da troca de mensagens entre os gregos e os troianos. Como um nome esperado para um troiano, Ideu é seguramente um personagem fixado na história; cf. Wathelet, 1988, i p. 599-600, $₫ 158$.

${ }^{47}$ Cf. Liberman, 1999, ad loc., p. 172 e n. 349. A fonte para esse fragmento, o papiro Amônio ad Ilíada,

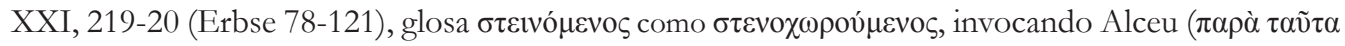

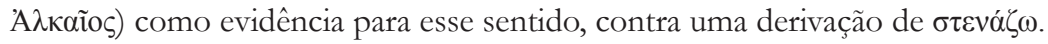

${ }^{48}$ Richardson, 1993, p. 53-4.

${ }^{49}$ Cf. West, 1997, p. 392 e 2007, p. 491.

${ }^{50}$ Texto de acordo com Obbink, 2006. 
Existem, portanto, alguns poucos casos muito bons para a interação lésbia com a poesia de Homero. Talvez isso não deva nos surpreender, dado o fato bastante importante de que "materiais da Odisseia não desempenham em Safo e Alceu nenhum papel reconhecível." 51 O caráter tradicional da epopeia, a existência e a perda de outros poemas detalhando o material da guerra de Troia, todos esses fatores militam contra a maior parte das identificações, deixando de lado as desvantagens adicionais e por vezes debilitadoras da preservação incompleta da poesia de Safo e de Alceu. Mas, mesmo se concedermos a interação nesses casos, o tipo de engajamento que está sendo sugerido não é particularmente exigente, e não indica uma dinâmica sustentada com todo o texto: alguns grandes episódios envolvendo os maiores personagens podem ser referenciados, mas requerem um conhecimento abstruso ou detalhado da Ilíada e da Odisseia, ou de seu entramamento no poema-alvo. ${ }^{2 *}$

A figura um pouco anterior, e espartana, de Álcman apresenta a mesma figura geral. O primeiro candidato vem do famoso Parthéneion (fr. 1.45-9): ${ }^{.3}$

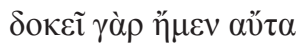

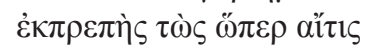

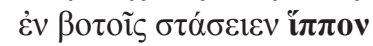

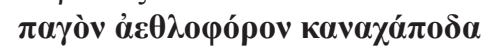

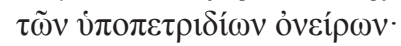

A expressão em negrito foi ligada com a descrição dos cavalos premiados de Agamêmnon (Ilíada, IX, 123-4 = 265-6), ${ }^{54}$ que vem no contexto da sua oferta de compensação a Aquiles:

$$
\delta \omega ́ \delta \varepsilon \kappa \alpha \delta^{\prime \prime} \text { "i } \pi \pi 0 v \varsigma
$$

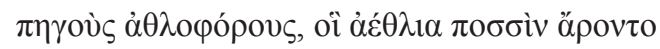

\footnotetext{
51 "Stoffe der Odyssee spielen bei Sappho und Alkaios keine erkennbare Rolle", Meyerhoff, 1984, p. 13. Isso poderia servir a um propósito puramente corizôntico, mas poderia também indicar que 'Homero' ainda não era muito bem conhecido pelos lésbios no começo do século VI a.C. Lembre-se também de que a Odisseia não deixa traço na arte do século VII a.C., e somente poucos e restritos traços no século VI a.C.; cf. acima, p. 126 e 127 e abaixo, p. 144, n. 81. [N. do T.: "corizôntico", adj.: relativo aos que sustentam a tese de que a Iliada e a Odisseia foram compostas por autores diferentes (do verbo grego khorizein = "separar")].

${ }^{52 *}$ N. do T.: O neologismo "entramamento" traduz "emplotment" do texto original, um termo técnico da teoria literária em inglês que deriva de "plot", "trama de uma narrativa", e significa "inserção de um acontecimento novo na trama de uma narrativa".

${ }^{53}$ Cf. Hutchinson, 2001, p. 71-6, para uma introdução geral, e p. 76-102, para um comentário sobre esse poema; também Ferrari, 2008, embora ela não discuta o caso presente.

${ }^{54}$ Cf. a caução admirável de Hutchinson, 2001, p. 87. Calame, 1977, ii p. 67-8, dá mais ênfase a um outro símile do canto II da Ilíada, no qual Agamêmnon é comparado com um touro no meio do rebanho (II, 480-4).
} 
Se é admitida a alusão, então Gregory Hutchinson bem pode estar certo ao sugerir que ela destaca a excepcionalidade de Hagesícora, ${ }^{55}$ i.e. por Álcman reduzir os doze cavalos de Agamêmnon a um, mas uma vez mais notamos que isso não é uma interação mantida com todo o texto, ou mesmo com a passagem iliádica mais ampla (que quase inteiramente anularia o sentido do elogio). Ao contrário, ela é um outro exemplo de análise que puxa a brasa para a própria sardinha, aqui uma frase inusual de um episódio de destaque, embora ele indique pelo menos um engajamento com um detalhe textual. ${ }^{56^{*}}$

Mas deveríamos assumir em primeiro lugar que Homero foi o primeiro ou único

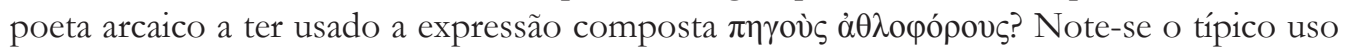

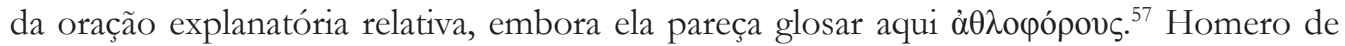
fato explica palavras bem conhecidas dessa forma ${ }^{58}$ mas ele também a usa muito mais frequentemente para descrever palavras, expressões compostas ou ideias que sejam menos

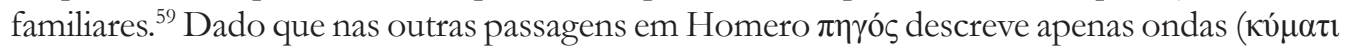

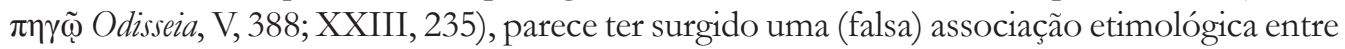
$\pi \eta \gamma o ́ \varsigma$ e $\pi \eta \gamma \eta ́$ na linguagem da epopeia grega mais antiga. ${ }^{60}$ Ou seja, poetas épicos tinham reinterpretado ou reconfigurado o sentido de $\pi \eta \gamma o ́ \varsigma$ à luz da sua associação formulaica (e sonora) com a água. No canto IX da Ilíada, $\pi$ $\gamma$ oúc deve ser explicado como uma sobrevivência mal compreendida, que a glosa deveria evitar. ${ }^{61}$ Que o termo tenha confundido todos os

\footnotetext{
${ }^{55}$ Cf. Hutchinson, ibid.

${ }^{56 *} N$. do T.: Por "análise que puxa a brasa para a própria sardinha" traduzo - com a anuência do autor - a expressão inglesa "cherry-picking", "colheita de cerejas", usada neste texto para indicar uma pesquisa que interfere nos próprios resultados, selecionando para exame apenas ou majoritariamente exemplos que favoreçam uma determinada conclusão.

${ }^{57}$ Assim também Rank, 1951, p. 82.

${ }^{58}$ Cf. Rank, 1951, p. 82-4.

${ }^{59}$ Cf. Rank, 1951, p. 76 e 76-82 mais geralmente. Para a familiaridade de Homero com esse composto,

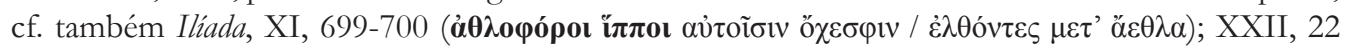

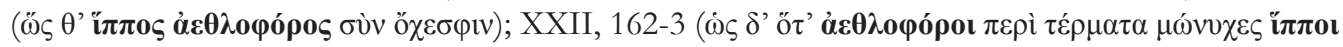

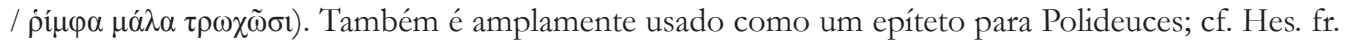
23a.39, 198.8, 199.1 MW, Cípria fr. 15.6 B. Para um exemplo de diversos itens em uma oração prévia sendo glossados dessa forma, cf., p. ex., Ilíada, XVI, 260-2.

60 "Falsa" somente no sentido de que sua derivação original (provavelmente independente) de $\pi \eta^{\gamma} \gamma v \mu$ u

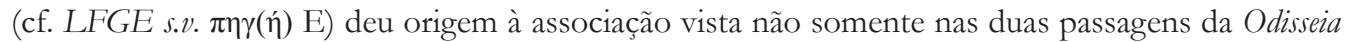

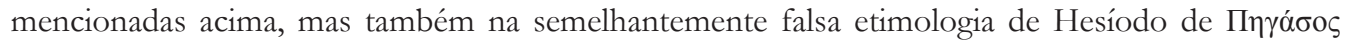

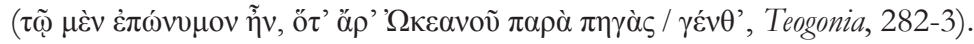

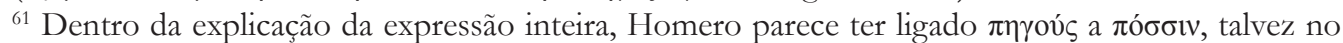
sentido de ser "firmemente fundada" ou "forte na fundação" (< $<\eta ́ \gamma v v \mu 1)$, como são as ondas na Odisseia; cf. LFGE s. $\pi \eta \gamma$ ó para esse sentido; diferentemente Calame, 1977, ii p. 68 n. 41: "a harmonia física do cavalo" ("l'harmonie physique du cheval"), mas ele baseia sua interpretação em Hesíquio (cf. próxima nota).
} 
intérpretes posteriores sugere certamente uma história por trás do desenvolvimento de Homero que agora somos incapazes de ver. ${ }^{62}$ fr. $80: 63$

Um caso mais perturbador nos vem em um e meio hexâmetros dactílicos de Álcman

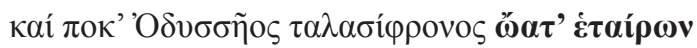

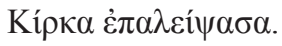

Embora ela mesma não o faça, ${ }^{64}$ a Circe homérica adverte Odisseu para que unte o ouvido de seus companheiros com cera antes de chegarem às Sereias (Odisseia, XII, 47-9):

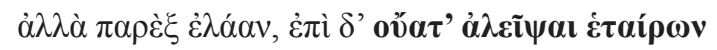

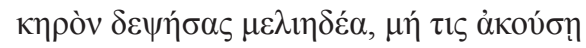

$\tau \tilde{\omega} v \ddot{\alpha} \lambda \lambda \omega v \cdot$

Entretanto, anteriormente no encontro deles, ela restaura sua forma untando-os com uma outra droga (Odisseia, X, 31-2):

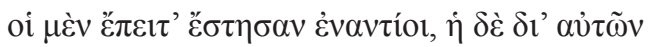

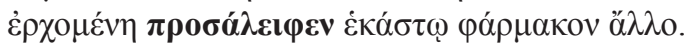

O modo de Álcman exprimir-se parece mais próximo do primeiro caso; a própria ação, do segundo. Poderíamos suspeitar de uma recombinação inteligente de dois episódios odisseicos em um, ou mesmo de uma rememoração equivocada, não fosse pelo fato de que Circe já é conhecida de Hesíodo, segundo quem ela tem filhos com Odisseu (Teog. 1011-16):

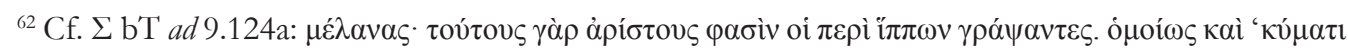

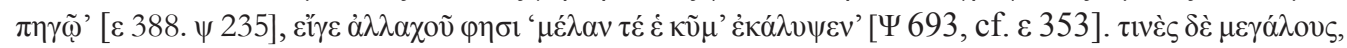

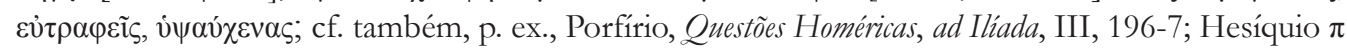

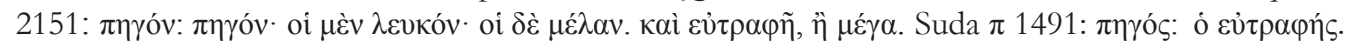
Hinge, 2006, p. 263: “infelizmente não sabemos o que Álcman tinha em mente" ("was Alkman sich vorgestellt hat, wissen wir leider nicht').

${ }^{63}$ West, 1988, p. 151, n. 4 = 2011, p. 36, n. 4, sugere que esses versos (transmitidos com jônicos $\pi$ o ${ }^{\prime}$

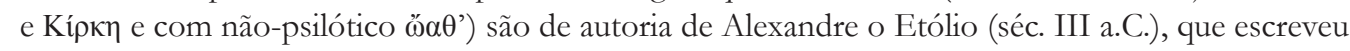
uma Kirka (Fr 5 Lightfoot) e, por outro lado, estava claramente interessado na Grécia ocidental, o cenário natural para uma história assim; cf. $\Sigma$ D ad Ilíada, XVI, 235 (fr 13 Lightfoot): A A

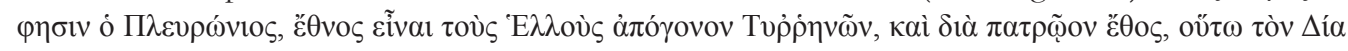
$\theta \rho \eta \sigma \kappa \varepsilon v ́ \varepsilon v$. Todavia, Ateneu vii 283A exprime dúvida sobre a autenticidade do poema (cf. Powell, 1925, ad loc., 122), os scholia vetera homéricos frequentemente citam Álcman, e não há nada textualmente desajustado no scholion, então a sugestão deve permanecer não-comprovada.

${ }^{64}$ A fonte para esse fragmento, o scholion (b)T para Ilíada, XVI, 236, de fato invoca a citação para

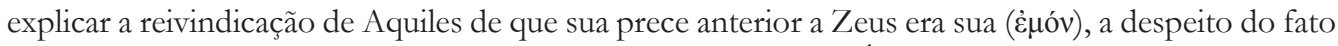
de que foi feita por Tétis. Portanto, o escoliasta entendeu que Álcman não concluiu que a própria Circe tinha aplicado a droga, embora sem um contexto maior seja difícil saber o quão longe levar isso. Em todo caso, se pudéssemos ter certeza de que Álcman e Homero tiveram a mesma versão de uma história tão popular (ver acima), isso não precisaria provar uma relação entre eles. 


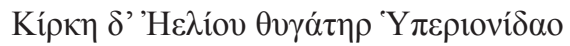

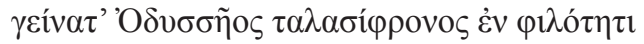

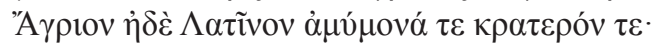

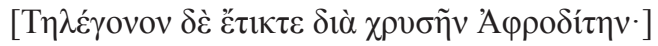

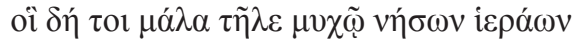

1015

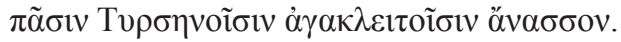

Embora essa passagem possa ou não ser Hesíodo autêntico, Latino poderia ter entrado na tradição grega em qualquer ponto do século VIII a.C. em diante, quando o contato e o comércio com a Itália começaram seriamente. ${ }^{65}$ Esta passagem da Teogonia conhece, portanto, uma história diferente sobre seu encontro com Odisseu e seus homens - então Álcman também pode tê-la conhecido, especialmente se considerarmos a profunda antiguidade da própria Circe. ${ }^{66}$

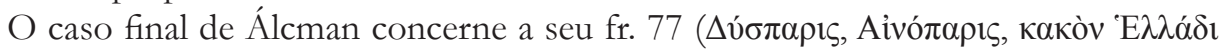
$\beta \omega \tau \imath \alpha v \varepsilon i ́ p \alpha \imath)$, cuja expressão bastante impressionante é invocada por um escoliasta homérico ${ }^{67}$

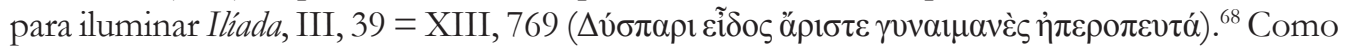

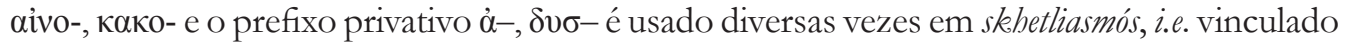
na epopeia grega antiga a palavras de modo a criar uma forma derrogatória dessa palavra; ${ }^{69}$ esse é um tipo comum de expressão figurativa com muitos paralelos indo-europeus. ${ }^{70} \mathrm{~A}$ partir daí, e voltando também os olhos para a importância tradicional óbvia desse personagem, é difícil acreditar que Homero tenha sido o primeiro ou único poeta épico grego a ter um personagem que aviltou Páris dessa forma. Mas de novo, se essa é uma interação homérica, não podemos avançar muito adentro do poema de Álcman, ou especular sobre a sofisticação

${ }^{65}$ Cf. West, 1966, p. 436 ad Teogonia, 1016, embora tente argumentar por uma conexão na metade do século VI (uma ligação anterior "pode ter causado pouca movimentação nas terras natais"); mais discussão recente em Lane Fox, 2008, p. 132-7 e ss.

${ }^{66}$ Cf. Hinge, 2006, p. 257, que sugere que o fragmento "provavelmente é impensável sem a Odisseia" ("ist wohl ohne Odyssee undenkbar"), embora depois sugira que Álcman "não tivesse diante dos olhos a nossa versão da Odisseia" ("die uns bekannte Fassung der Odyssee nicht vor dem Augen hatte" - i.e., ele de fato tinha "alguma versão", "irgendeine Fassung”, dela); cf. abaixo, n. 68. Entretanto, uma vez mais ele não vê o contexto no qual o fragmento é citado pelo escoliasta (acima, n. 64).

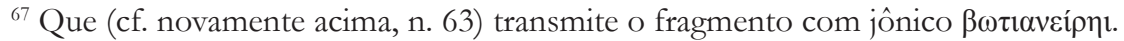

${ }^{68}$ Cf. a discussão em Fowler, 1985, p. 30; Hinge, 2006, p. 257, embora observe-se a caução na sua expressão: "é geralmente aceito que Álcman tenha conhecido as epopeias homéricas ao menosparcialmente e em alguma versão" (grifos meus) ("dass Alkman die homerischen Epen zumindest teilweise und in irgendeiner Fassung gekannt hat, wird allgemein angenommen”); contra Calame, 1983, ad loc., p. 489-90.

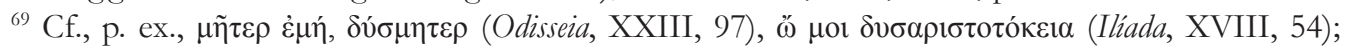

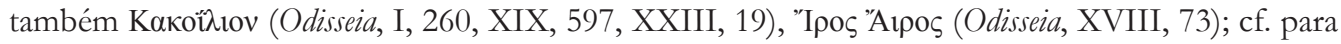
mais exemplos Risch, 1974, p. 215; Fehling, 1969, p. 287-9 e 176. Hinge, 2006, p. 299, de modo irreal toma exemplos posteriores desse fenômeno na tragédia como originando-se de Álcman!

${ }^{70}$ Cf. West, 2007, p. 80-3; embora um composto por formação (cf. West, 2007, p. 79-80), esse exemplo na Ilíada é usado como uma expressão composta. 
intertextual no engajamento. O nome é bastante impressionante (como talvez com $\pi \alpha ́$ yov acima) e nos leva a especular sobre a necessidade de ter havido mais algum objetivo interativo.

Para resumir: o que aconteceu em Lesbos com Alceu e Safo, no primeiro terço do século VI a.C., também teria ocorrido em Esparta com Álcman no último terço do século VII a. C. A figura é admiravelmente uniforme no que ela está - ou no que não está - dizendonos sobre interações homéricas nesses poetas. Mas, antes de chegarmos à figura um pouco posterior do próprio Estesícoro, também é bom considerar o caso de outro grego ocidental, desta vez um dos seus contemporâneos, Íbico de Régio, e a famosa "Ode de Polícrates" (S 151). ${ }^{71}$ Há diversas sugestões de interação homérica nesse poema, mas as duas mais populares são a descrição de Ájax e Aquiles como principais heróis da expedição (v. 33-4), e o momento (anti-?) Dichterweihe $e^{72 *}$ do poeta $(23-5 s s.){ }^{73}$ No primeiro caso, Ruby Blondell sugere que essa é uma "alusão manifesta" ao Catálogo das Naus (Iliada, II, 768-70):

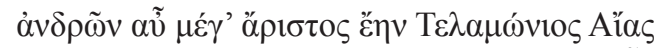

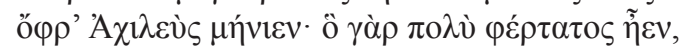

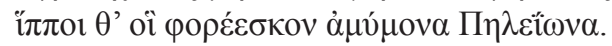

Entretanto, a menção a Ájax como segundo melhor nesta passagem é obviamente herdada pelo poeta homérico, e não somente porque ele compõe constantemente contra isso - p. ex., tornando Diomedes o representante de Aquiles na primeira metade do poema, e dando a Ájax de longe o tempo mais difícil, e elevando-o à proeminência militar apenas uma vez que os maiores heróis gregos estão feridos e fora de ação, e fazendo com que saia como segundo melhor em todas as três das suas competições nos Jogos Fúnebres. Homero também reflete a posição relativa deles em outra parte (Odisseia, XI, 470, 551; XXIV, 18), e

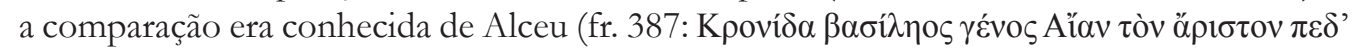

${ }^{71}$ Cf. Barron, 1969; Hutchinson, 2001, p. 235-56; Wilkinson, 2013, p. 50-87; Bowie, 2010, p. 74-6; Blondell, 2010, p. 361-72; também Graziosi, Haubold, 2009, p. 102.

${ }^{72^{*}}$ N. do T.: Dichterweihe, "sagração do poeta", é uma expressão alemã usada para designar o momento decisivo da iniciação e aquisição do estatuto de poeta.

${ }^{73} \mathrm{O}$ limite de espaço impede a discussão de mais exemplos, embora eu note aqui que Wilkinson, 2013, p. 78, segue Hutchinson, 2001, 248-9, ao argumentar que os epítetos 'homéricos' em

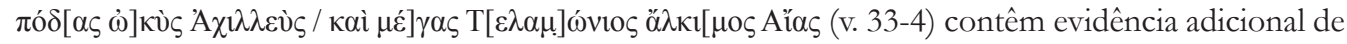
uma relação direta, entretanto a primeira frase é uma expressão tradicional (Hutchinson estranhamente a chama de "unicamente iliádica"), enquanto a segunda é composta de expressões tradicionais ( $\mu \varepsilon ́ \gamma \alpha \varsigma$

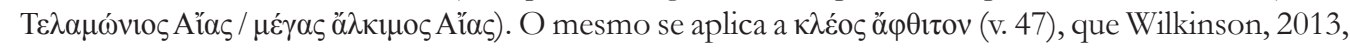
ad 47, p. 85-6, pensa que "deve aludir a Ilíada, IX, 413" (e também porque cai “em um poema com tantos ecos homéricos”), todavia sua nota sobre o termo mostra o quão tradicional é a expressão, já em Hesíodo fr. 70.5 MW (não mencionado por Wilkinson), Safo fr. 44.4 (ver acima, n. 45), e Carmina

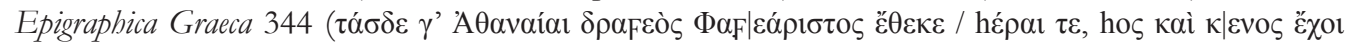

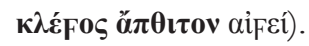




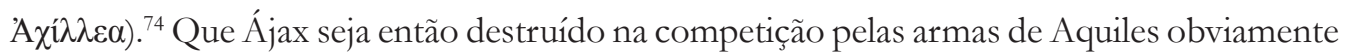
também é significativo de uma ligação entre eles, bem como a maneira pela qual Ájax assume o manto do principal antagonista de Odisseu entre os gregos em Troia, depois do decesso do maior herói. Com certeza, isso não se restringe a três linhas do canto II da Ilíada. De fato, quando Íbico se põe a falar de "Cianipo" como o mais belo dos gregos (onde Homero tinha essa figura como Nireu), podemos certamente concluir que uma dependência da, ou alusão à, Ilíada está longe de ser necessária. ${ }^{75}$

E quanto à afirmação de Íbico do seu relacionamento com as Musas (v. 23-5ss.), o caráter tradicional e ubíquo desse tema na poesia grega antiga torna ao menos discutível que Íbico tenha aqui em mente uma postura "épica" generalizada, mais do que qualquer coisa especificamente homérica. ${ }^{76}$ Certamente típica é a noção de que as Musas podem cantar alguma coisa, ou alguma coisa a respeito da guerra de Troia, e a relativa inabilidade dos homens diante delas. Enquanto a recusatio se parece com Ilíada, II, 484-92, ao contrastar o divino com o mortal no que diz respeito ao canto, Íbico difere de Homero em não (explicitamente) usar as Musas como o único meio de confrontar a deficiência mortal, embora isso se pareça mais com uma desculpa para não criar narrativa épica detalhada no contexto desse poema do que com uma crítica generalizada das Musas ou da narrativa heroica, como os comentadores frequentemente concluem. ${ }^{77}$

No entanto, mesmo que se conceda isso, as alusões ou interações sugerem mais uma vez um pacote de destaques, onde Íbico está evocando elementos centrais do texto iliádico - a postura do poeta diante das Musas, o canto dos $\kappa \lambda \dot{\varepsilon} \alpha \dot{\alpha} v \delta \rho \tilde{\omega} v$ no canto IX da Ilíada, três personagens centrais (Agamêmnon é proeminente nos versos 20-22). Os estudiosos argumentaram que essas análises que puxam a brasa para a própria sardinha tornam o poema profundamente sutil e sofisticado, mas muito disso, se não tudo, permanece, se tomamos como fonte de significação noções menos especificamente homéricas, mas mais genericamente épicas: Barbara Graziosi e Johannes Haubold vêem persuasivamente um relacionamento mais nuançado entre a lírica e diversos outros tipos de poetas épicos inerentes

\footnotetext{
${ }^{74}$ Os mesmos argumentos falam contra a conexão feita entre esse fragmento de Alceu e a Ilíada; cf. Meyerhoff, 1984, p. 13, n. 82.

${ }^{75}$ Cf. Wilkinson, 2013, ad 32-33, p. 78: “ele não é somente dependente de Homero" (grifo meu).

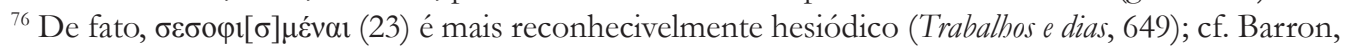
1969, e Steiner, 2005, para o argumento de que Íbico está interagindo com Hesíodo.

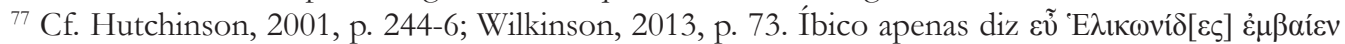

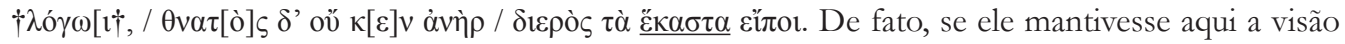
que lhe é frequentemente atribuída, é estranho que ele só não gaste os últimos dois versos do poema (tal como nos chegou) falando de Troia. Esse tipo de análise conduzida como um desenvolvimento é muito comum, como Graziosi; Haubold, 2009, p. 98, nos advertem: "pode ser tentador encaixar esses tratamentos diferentes das Musas em uma narrativa de desenvolvimento: desde apelos antigos e ingênuos por informação, como encontrados na epopeia, até reflexões sofisticadas sobre habilidade poética, como atestadas na poesia lírica."
} 
à afirmação da Musa, ${ }^{78}$ enquanto a autoridade política de Agamêmnon, a pura força marcial de Aquiles e Ájax, e a beleza de Troilo na tradição heroica (na medida em que podemos reconstruí-la) os tornam todos excelentes figuras paradigmáticas para Polícrates. ${ }^{79}$ Mesmo assim, no entanto, não é muito que é pedido do conhecimento da audiência da própria Ilíada.

Em suma, nesses muito poucos casos que poderiam ultrapassar a nossa baliza de evidência, o nível de engajamento - onde podemos especular - é distante, superficial e muito limitado. Nada muito relevante sobre o texto é revelado ou aparentemente desdobrado, e não se pede à audiência para entramar muito desse texto no poema lírico. ${ }^{80}$ Qualquer que seja a interação que há aqui, ela não sugere um redesdobramento do texto homérico mais do que uma puxada de brasa para a sardinha dos seus temas, personagens e (talvez, como com Álcman fr. 1 ou 77) expressões mais famosos.

É suspeito que isso corresponda tão bem à evidência de representações artísticas do material da guerra de Troia no perído arcaico: ${ }^{81}$ cenas homéricas permanecem minoritárias bastante adentro do século VI a.C., enquanto a Ilíada e especialmente a Odisseia parecem impor somente uma pequena variedade de episódios "famosos" à tradição artística. Como Andrew Ford mostrou, ${ }^{82}$ esse também foi o destino literário comum de Homero no período arcaico: ser invocado como um grande e autorizado poeta épico sem que essa invocação demande conhecimento detalhado ou contínuo dos seus textos propriamente ditos. Em suma, a recepção homérica desses poetas não sustenta a imagem de uma cultura poética alusiva, altamente literária na Grécia arcaica. Como na epígrafe a este artigo: "Não há Virgílios aqui."》33

\section{A distinção de Estesícoro}

Tudo muda com Estesícoro. Ele é uma anomalia de outro modo, mais visivelmente por tentar compor com dáctilos líricos e com um dialeto épico-dórico a abrangência e o

\footnotetext{
${ }^{78}$ Graziosi; Haubold, 2009, p. 97-9.

${ }^{79}$ É um pouco mais difícil saber o que fazer de Cianipo (ou do Zeuxipo restaurado), v. 37-40; cf. Hutchinson, 2001, ad loc., p. 250-1; Wilkinson, 2013, ad loc., p. 79-80.

${ }^{80}$ Bowie, 2010, p. 84, conclui seu levantamento de interações líricas assim: “o que perdemos até aqui é um questionamento prolongado do ideal heroico ou do modo como os deuses homéricos se comportam tal como vemos na literatura do final do século V.” Esse tipo de engajamento ou, talvez melhor, a ausência de um engajamento crítico posterior nas recepções poéticas de Homero no século V pode também não estar desconectada da falta de intertextualidade "sofisticada" ou de engajamento contínuo nas recepções arcaicas.

${ }^{81}$ Cf. acima, n. 51. Também deveríamos lembrar-nos de que não há evidência de inscrição de versos homéricos até o final do século V a.C.; cf. Lowenstam, 1997, p. 45-8.

${ }^{82}$ Ford, 1997.

${ }^{83}$ Fowler, 1987, p. 39. Vale a pena citar a passagem inteira: “a imagem geral que emerge para o século VI é a mesma para o VII. Todavia, há imitações mais certas ou quase certas da poesia de Homero na forma em que o conhecemos, e alguns exemplos nos quais os poetas pedem à audiência que faça suas próprias inferências sobre a relação da cópia com o modelo. Entretanto, nenhum poeta usa uma técnica de imitação que depende de mudanças sutis em palavras individuais; não há Virgílios aqui."
} 
corpus de um poeta de uma narrativa de estilo épico. ${ }^{84}$ Não há surpresa de que a extensão do seu epicismo seja mais óbvia, porque poetas líricos anteriores não estavam tentando escrever narrativa autocontida nessa escala, e o material heroico épico permancece largamente minoritário nos seus corpora, enquanto para Estesícoro esse tipo de composição é quase tudo o que conhecemos e temos da sua obra. Além do mais, sua falta de conexão lírica típica com uma circunstância contemporânea não é apenas um acidente de transmissão, porque a tradição biográfica também não foi de fato capaz de fazer muito uso da sua poesia. ${ }^{85}$

Há então uma diferença real entre Estesícoro e os outros poetas líricos. A sua abordagem admite naturalmente mais oportunidade de interação com Homero (e, claro, também com outra poesia épica), muito particularmente em termos de seleção. ${ }^{86}$ Isto é, Estesícoro se move além de detalhes que poderíamos encontrar em Álcman, Safo, Alceu e Íbico, que poderiam estar retomando e/ou reelaborando elementos homéricos que envolveram os principais personagens nos principais momentos dos poemas: Páris sendo maltratado por Heitor, Heitor despedindo-se de sua mulher ou tendo sua morte lamentada, Aquiles lutando com o rio ou cantando sozinho em sua tenda, Odisseu e Circe etc. Como vimos com os artistas arcaicos, a prática do poeta era uma abordagem de "pacote de destaques" da interação homérica.

Mas em Estesícoro, como primeiro argumentou Walter Burkert trinta anos atrás, finalmente chegamos além disso. ${ }^{87}$ Primeiramente, na Gerioneida (fr. S 15 col. ii) Héracles atira uma flecha através de uma das três cabeças de Gerião (8-17):

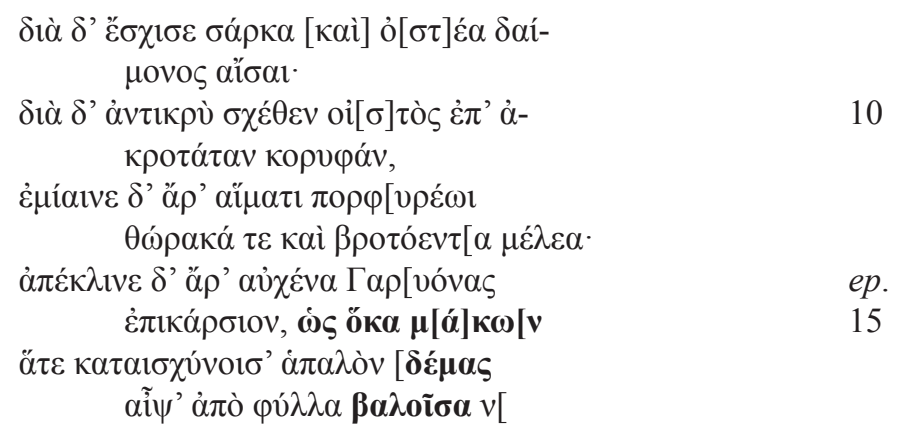

O sorriso de papoula (15-7), como já foi notado há muito tempo, ${ }^{88}$ tem mais do que uma semelhança casual com a descrição homérica da morte de Gorguitião (Ilíada, VIII, 302-8):

\footnotetext{
${ }^{84}$ Para estudos básicos de Estesícoro nessa veia, cf. Maingon, 1989; Arrighetti, 1994; Russo, 1999; Curtis, 2011, e agora Davies; Finglass, 2014.

${ }^{85}$ Cf. Kivilo, 2010, p. 63-86.

${ }^{86}$ O famoso caso da Palinódia é obviamente importante aqui; cf. Kelly, 2006 e Davies; Finglass, 2014, ad loc. Esse poema foi amplamente considerado na Antiguidade como indicativo de uma postura antihomérica, e mostra, de um outro ângulo, uma percepção antiga de que Estesícoro tinha uma relação particular com o passado homérico; cf. Graziosi; Haubold, 2009, p. 108-9.

${ }^{87}$ Burkert, 1987.

${ }^{88}$ Cf. Maingon, 1980; também Curtis, 2011, ad loc., p. 146-7.
} 


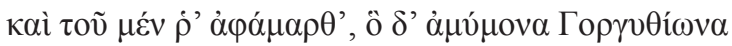

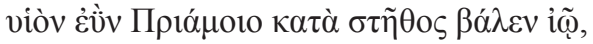

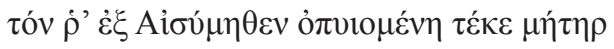

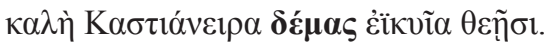

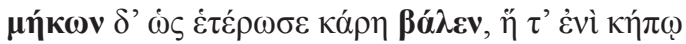

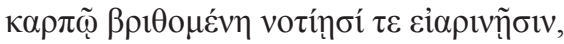

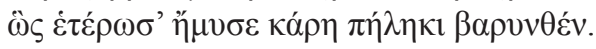

Agora o ceticismo entra em ação: flores e plantas não são incomuns em tais circunstâncias na epopeia grega arcaica, ${ }^{89}$ e a imagem é diferente - papoula soltando suas folhas, papoula pesada com o fruto e a água da primavera. Ainda por cima, achamos a cabeça da papoula (kódeian) sendo desdobrada em outro lugar, em um símile homérico de uma cabeça decapitada (Ilíada, XIV, 496-500):

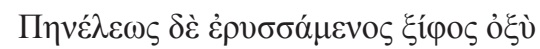

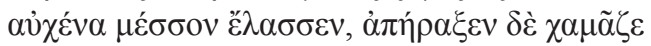

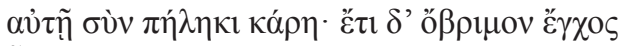

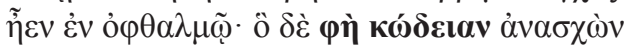

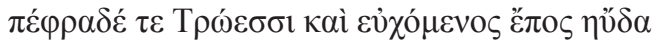

De fato, somente $\mu \eta ́ \kappa \omega v$ é partilhada por duas passagens - embora se possa também apontar a repetição (com variatio) de $\beta \alpha \lambda$ oĩ $\alpha \alpha$ e $\beta a ́ \lambda \varepsilon v$, e (se o suplemento $\delta \varepsilon ́ \mu \alpha \varsigma$ em v. 16 é correto) a repetição uma vez mais de $\delta \varepsilon ́ \mu \alpha \varsigma$ deslocada da menção biográfica da mãe de Gorguitião na Ilíada (VIII, 304-5) ao próprio Gerião. Uma tal recomposição deliberada da fraseologia épica em Estesícoro foi documentada extensamente por estudiosos como Alison Maingon e Evanthia Tsitsibakou-Vasalos, ${ }^{90}$ de modo que não ficaria deslocada aqui. Mas $\mu \eta ́ \kappa \omega v$ não ocorre novamente na poesia até Aristófanes, e a chance de que a mesma imagem de símile, altamente atípica, tivesse sido aplicada a duas passagens desconexas a uma figura atingida por uma flechada - um meio de vitória claramente incomum em Homero - deve ser muito pequena.

Além do mais, diferentemente das interações anteriores, este não é de forma alguma um episódio proeminente na Ilíada: o vencedor é Teucro; a vítima, o filho, de outro modo desconhecido, de Príamo, Gorguitião (cf. Apolodoro III, 152) - um nome seguramente sugestivo para um poeta compondo sobre Gerião ${ }^{91}$ - mas que é ele próprio uma figura menor,

\footnotetext{
${ }^{89}$ Cf. Kelly, 2007, p. 153-4.

${ }^{90}$ Cf. Maingon, 1978, 1980, 1989; Tsitsibakou-Vasalos, 1986, 1990; também Vagnone, 1982. Rocha, 2009; Curtis, 2011, p. 48-9. Por razões que ficarão claras, sou cético a respeito de muitas dessas identificações.

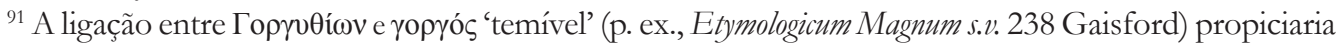
uma fácil associação com o espetáculo bastante aterrorizante de Gerião, uma vez que ele foi, afinal de contas, neto de Medusa através de seu pai Crisáor (que é mencionado na Gerioneida; fr. S 10.5); cf.

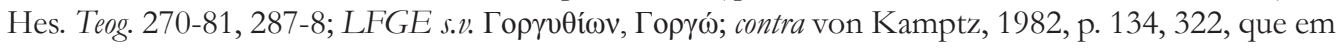
vez disso o vincula com os $\Gamma \dot{\varepsilon} \rho \gamma \imath \varepsilon \varepsilon \varsigma$, habitantes do norte de Troia.
} 
morta por engano por Heitor, e cuja morte acontece durante uma das menos importantes ou memoráveis sequências do poema. Se aceitamos essa interação, o que ela revela sobre o nível e o tipo de engajamento de Estesícoro com a Ilíada?

Pode-se considerar nessa conexão que a história da mãe de Gorguitião, Castianira seu casamento e o nascimento do seu filho -, é mencionada imediatamente antes do símile na Ilíada, talvez relembrando a cena estendida entre Gerião e sua mãe em Estesícoro (fr. S 11 e 13). Mas, na melhor das hipóteses, isso é digno de esperança. Eu limitaria a interação ao fato de que, como o símile de Homero concede um tremendo páthos a um guerreiro desconhecido morto por engano, então este símile procura usar a fonte homérica para atribuir ao monstruoso Gerião um nível de sentimento similar. ${ }^{92}$ Se se quisesse obter uma visão mais esperançosa das interações na poesia lírica examinadas anteriormente, elas poderiam sugerir que Estesícoro difere delas somente por tomar um episódio menor em vez de um maior, e por desdobrá-lo em uma história determinadamente não-homérica. Talvez isso seja um avanço suficiente, mas por sorte esse exemplo também pode ser lido em conjunção com o próximo caso, também da Gerioneida.

Trata-se da famosa exibição dos seios maternos em S 13.5 e Ilíada, XXII, 83. Primeiro, o fragmento de Estesícoro:

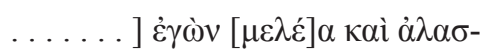

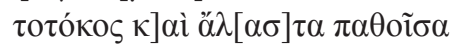

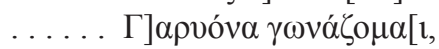

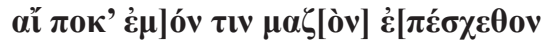
$\ldots \ldots \ldots . \ldots \mu$........ $\gamma$

........]

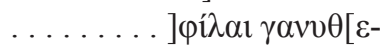

......... ] ]обóvars ]$\mu \cdot[$

ep.

Agora a passagem da Ilíada (XXII, 82-3), quando Hécuba se dirige a seu filho:

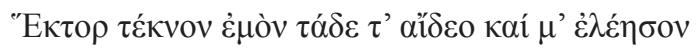

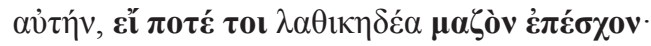

O tema se torna extremamente popular mais tarde na tradição trágica, ${ }^{93}$ mas só é encontrado nessas duas situações na literatura arcaica. ${ }^{94}$ É claro que há o perigo de circularidade aqui, na medida em que a passagem homérica teve uma influência óbvia sobre o (universalmente aceito) suplemento de Estesícoro. Mas mesmo se algo deveria ser mudado no suplemento, há ainda a apresentação, ou reminiscência da apresentação, do seio materno à

\footnotetext{
${ }^{92}$ Cf. Curtis, 2011, ad loc., p. 148-50.

${ }^{93}$ Cf. Garvie, 1986, ad Coéf. 896-8, 292-3 para referências; também Curtis, 2011, ad loc., p. 116-7.

${ }^{94}$ Pode-se também considerar o episódio no qual Menelau deixa sua espada cair ao ver os seios de Helena na Pequena Ilíada (fr. 19 Bernabé) como uma outra forma desse tipo de ação.
} 
sua criança como parte de uma súplica de não sair e lutar contra um inimigo opressivamente perigoso. Isso derrota mesmo o ceticismo do presente autor.

Outras, e mais precisas, interações homéricas nessa cena foram propostas: Alison Maingon, por exemplo, sugeriu que o fr. S 13.2-3 combinou diversas expressões da mesma passagem da Ilíada que, se há uma conexão no v. 5, deve ser mais do que plausível. ${ }^{95}$ Mas o vínculo verbal não é tão forte, certamente não tão forte quanto o caso no v. 5, e Estesícoro deve ter conhecido cenas de lamentação - já que elas são traços altamente estilizados em outros poemas ou performances. Então eu hesitaria em colocar ênfase demais nessas semelhanças, já que isso seria apenas usar a identificação do engajamento no v. 5 como uma desculpa para OQVVETOQH.

Deixando essas de lado, então, a interação aqui é certamente de uma ordem diferente da daquelas que vimos até agora. Embora seja uma vez mais uma cena de destaque na Ilíada, neste caso tanto a ação quanto seu contexto mais amplo e alguma fraseologia (crucialmente) não-formulaica são espelhadas entre as passagens. Ainda por cima, quando combinada com S 15, essa passagem mostra Estesícoro consistentemente usando imagens da Ilíada que são (1) exclusivas deste poema, e (2) aplicadas nele aos troianos, de modo a preencher a caracterização de Gerião e da sua situação. Esse é um aumento perceptível no nível e na natureza continuada da interação homérica, e mostra Estesícoro usando um continuum da tribulação troiana na Ilíada de Homero, mais provavelmente para evocar simpatia pelo usualmente monstruoso Gerião.

Como um segundo exemplo do apreço de Estesícoro por episódios levemente rebuscados nos poemas homéricos, poderíamos considerar o fr. 209 (provisoriamente atribuído aos Nóstoi):

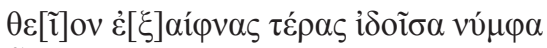

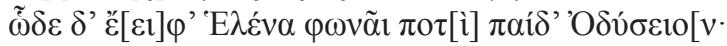

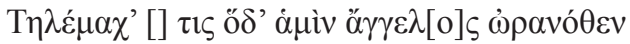

$\delta \imath^{\prime} \alpha i \theta \dot{\varepsilon} \rho 0[\varsigma \dot{\alpha} \tau] \rho v \gamma \varepsilon \dot{\tau} \alpha \varsigma \kappa \alpha \tau \dot{\varepsilon} \pi \tau \alpha \tau o, \beta \tilde{\alpha} \delta[$

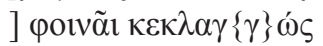

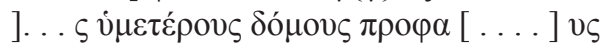

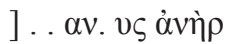

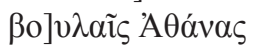

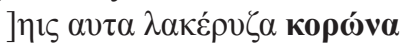

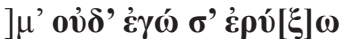

Esse foi comparado muito de perto com a partida de Telêmaco de Esparta no canto XV da Odisseia (especialmente 68, 160-78) - uma cena que, como diz Steve Reece, "não passa de um episódio menor em uma sub-trama da Odisseia". ${ }^{96}$ Há duas diferenças significativas entre os tratamentos: Helena interrompe Menelau para dar a sua interpretação na Odisseia

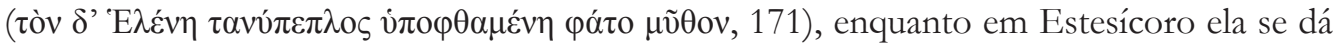

\footnotetext{
${ }^{95}$ Cf. Maingon, 1978, p. 281-2.

${ }^{96}$ Reece, 1988, p. 8.
} 
conta do sinal e fala primeiro (v. 1-2); o sinal na Odisseia é uma águia segurando um grou

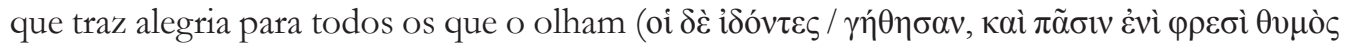

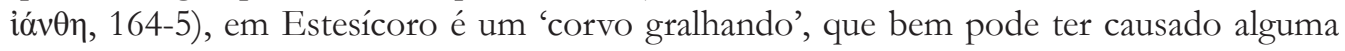
consternação. ${ }^{97}$

Note-se que Estesícoro dá muito mais autoridade a Helena, ao oferecer sua interpretação sem, aparentemente, qualquer consulta prévia a Menelau; note-se, também, que ele foca no fato de que ela viu sozinha o sinal, diferentemente da reação explícita dada à audiência interna de Homero. Esse favorecimento pode não nos surpreender em um poeta tão reconhecido por uma relação muito particular com Helena, mas o mesmo

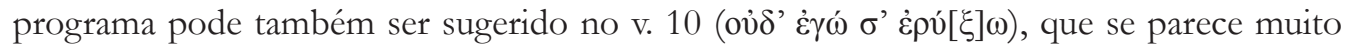

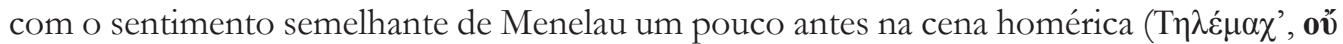

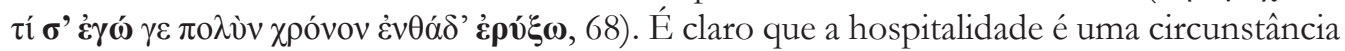
típica na epopeia grega antiga, mas não há outra afirmação de $1^{a}$ pessoa com esse objetivo em Homero. Com uma pequena trepidação, mas só uma pequena, eu sugiro que esse é mais um caso de Estesícoro retrabalhando explicitamente uma passagem homérica, seguindo uma interpretação de uma sequência inteira da narrativa de Homero, ou seja, o relacionamento entre Helena e Menelau em Esparta. Ele consegue isso transferindo elementos diretivos a Helena mais ou menos no final da cena de hospitalidade, e talvez também focalizando apenas na sua reação ao sinal. Esse é um redesdobramento levemente menos radical do que o na Gerioneida, quando os mesmos personagens e circunstâncias estão envolvidos como em Homero, mas a interação encoraja a audiência a pensar do mesmo modo.

É claro que outros casos de interação homérica específica em Estesícoro foram propostos, notadamente o nível e a manipulação da sua dicção épica, p. ex. na existência de fórmulas de introdução de fala. ${ }^{98}$ Isso dificilmente pode ser definitivo, já que a dicção formular poderia ser derivada de qualquer um dos muitos poemas e performances épicos com os quais Estesícoro e sua audiência estavam familiarizados. Mais tentador, talvez, é o paralelo

\footnotetext{
${ }_{97}$ Odisseia, IV, 164-5. A propósito, esse é um detalhe interessante, já que a expressão $\lambda \alpha \kappa \varepsilon ́ \rho v \zeta \alpha$

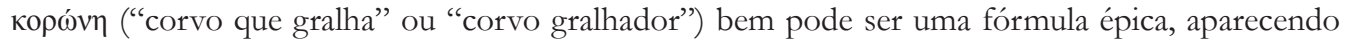
em Trabalhos e dias, 147, como um mau sinal, e em um fragmento hesiódico enigmático (fr. 304.1 MW) invocado uma vez mais em um contexto oracular. Corvos parecem ter sido típicos em maus sinais, o que teria ajudado a explicar o verso 5 ( estivesse fazendo com Hesíodo o que temos sugerido que fazia com Homero, i.e. redesdobrando passagens mais importantes e (como aqui) menos importantes em um contexto inteiramente novo. Épocas posteriores certamente o tomaram por ser tão agonístico com Hesíodo quanto com Homero, até fazendo dele o filho de Hesíodo em uma tradição, e a história da Palinódia envolveu ambos esses poetas no processo da narrativa de retratação. No entanto, uma vez mais, eu sou cauteloso; se corvos são convencionalmente maus sinais, não é sua aparência em (naquilo que nos chegou de) Hesíodo que pode estar influenciando Estesícoro aqui.

${ }^{98}$ Cf. acima, n. 85.
} 
temático entre a resposta de Gerião à cautela da sua mãe (?) e a famosa fala de Sarpédon sobre o êthos heroico no canto XII da Ilíada. ${ }^{99}$ Antes de mais nada, Estesícoro (fr S 11):

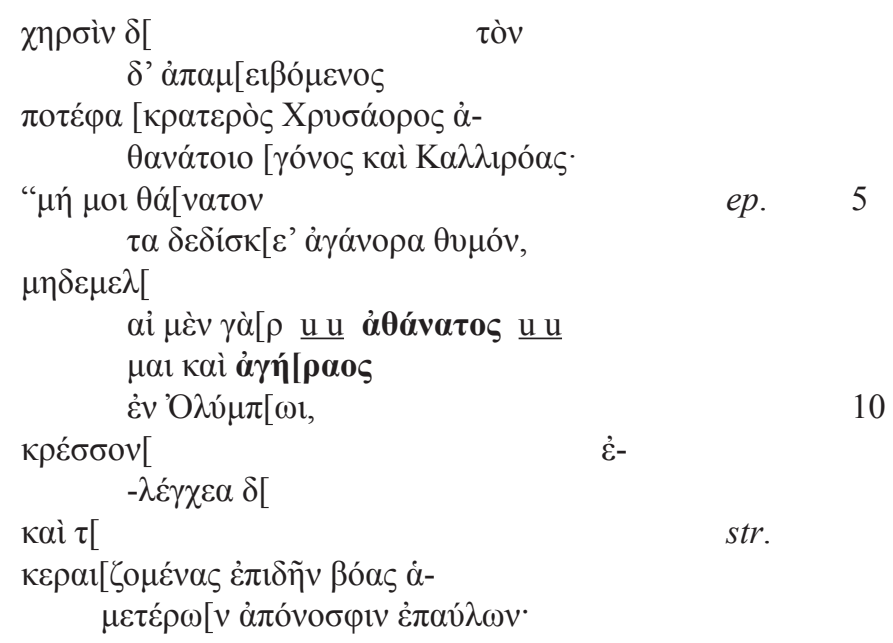

str.

Agora a passagem homérica, quando Sarpédon responde ao seu companheiro Glauco (Iliada, XII, 332-8):

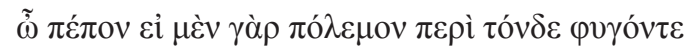

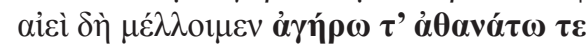

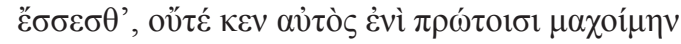

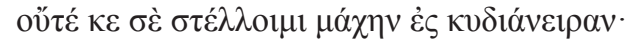

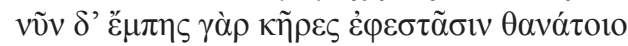

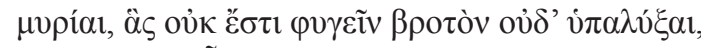

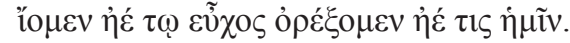

Não há, todavia, nenhum gatilho marcado para qualquer interação específica com a fala de Sarpédon, uma vez que o único caso possível ("imortal e isento de envelhecimemento", v. 8-9) depende da restauração e de qualquer modo é uma expressão formular que recorre frequentemente em situações onde o contraste entre mortal e imortal está sendo enfatizado. ${ }^{100}$

\footnotetext{
${ }^{99}$ Cf. Tsitsibakou-Vasalos, 1991-1992.

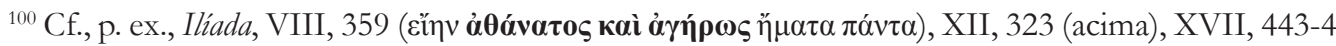

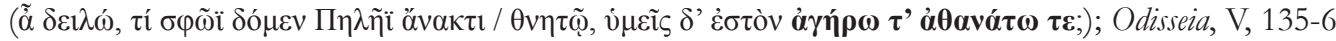

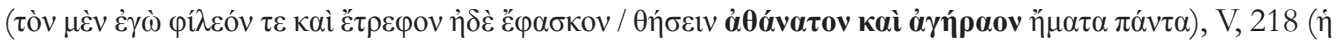

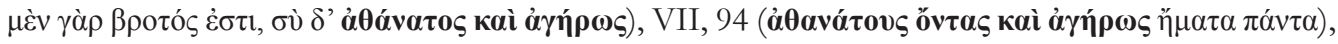

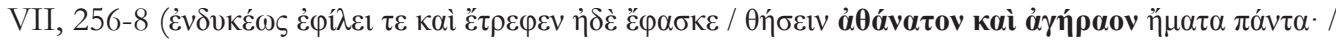

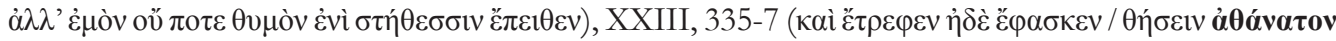

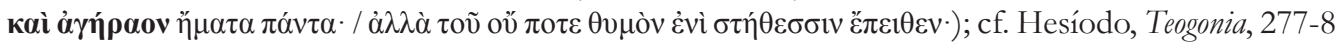

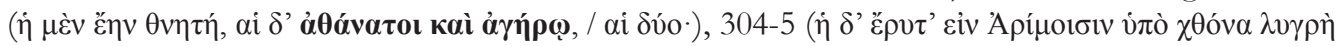

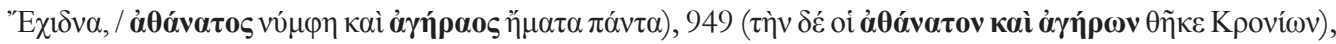

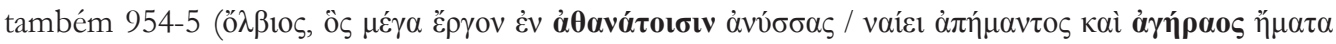


Embora não haja outro exemplo remanescente dessa fórmula na qual a comparação está sendo feita precisamente nesse contexto, sua formularidade arrasta esse caso para baixo da baliza. ${ }^{101}$ Entretanto, se ele conseguisse arrastar-se junto, propiciaria mais evidência para o uso de elementos especificamente troianos (ou, mais exatamente neste caso, não-gregos) da Ilíada por Estesícoro, de modo a angariar simpatia, ou ao menos admiração, por Gerião.

\section{Conclusão}

Estesícoro foi o mais épico de todos os poetas líricos arcaicos, e representa um estágio importante no que podemos dizer sobre a difusão e o desdobramento dos poemas de Homero no mundo grego. O nível de sua interação poética especificamente com a Ilíada e a Odisseia, e não somente com 'epopeia', parece ser claro em dois casos: (i) na Gerioneida ele pega dois episódios únicos da Ilíada e os combina de modo a sugerir uma leitura consistente do destino dos troianos no poema; e (ii) nos Nóstoi ele enfatiza o maior poder determinativo de Helena ao lhe conferir duas únicas ações que haviam sido dadas a Homero por Menelau.

Isso sugere que Estesícoro tinha acesso a mais do que apenas um conhecimento geral dos poemas, talvez mesmo a um texto escrito, mas também que a natureza da interação está se tornando mais afim à intertextualidade de uma época posterior: mais do que meramente mostrar conhecimento da Ilíada e da Odisseia, ou a figura de Homero como uma autoridade, ou até mesmo as partes dos seus poemas que poderiam incluir-se em um pacote de destaques, Estesícoro parece estar desdobrando uma leitura mais abrangente desses poemas ou amplos segmentos em seu interior (troianos como solidários, Helena como mais impressionante do que Menelau) de modo a dar vida ao sentido do seu próprio texto. Pela primeira vez que podemos ver, a audiência está sendo encorajada a entrar em contato com um poema inteiro $e$ seus detalhes, e a aplicar ativamente esse conhecimento à canção em curso.

Parcialmente, todavia, isso pode ser simplesmente uma questão de evidência e viés subjetivo: Safo fr. 44, por exemplo, poderia ser reivindicado como evidência para precisamente esse tipo de interação, e eu não ficaria muito chateado: no final das contas, eles são tão próximos em data que seria surpreendente se Estesícoro no oeste tivesse acesso a um texto completo de Homero, enquanto Safo e Alceu no leste, não.

Mas as diferenças entre Estesícoro e Safo ainda são perceptíveis: ela pode estar tomando uma faixa de episódios de destaque da Ilíada e recombinando-os em algo novo, sugerindo uma leitura de diversos episódios diferentes em um continum coerente, mas sua

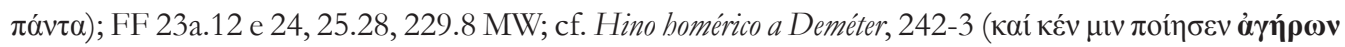

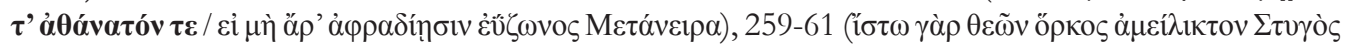

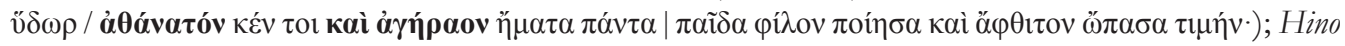

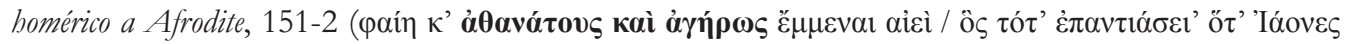

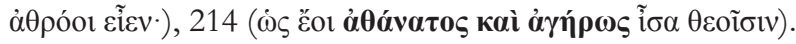

${ }^{101}$ Nota-se, todavia, que seu sentimento é particularmente próximo de Ilíada, VIII, 359 (cf. a nota

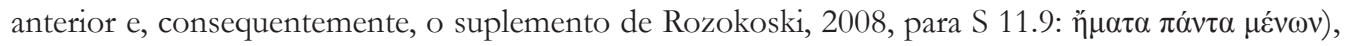
uma parte da Ilíada que com certeza Estesícoro estava usando na Gerioneida; cf. acima, p. 145 e 147. 
nova narrativa ainda tem a ver com os mesmos personagens e os mesmos acontecimentos tais como contados em Homero, eles estão apenas colocados no extremo oposto da sua história. Estesícoro, por outro lado, também toma episódios e expressões menos familiares, e os aplica a uma história completamente diferente na Gerioneida, assim como à (aparentemente) mesma história nos Nóstoi. Então talvez fosse mais razoável pensar que Estesícoro atinge um estágio mais avançado em um continuum de interação, levando além as potencialidades que foram exploradas por seus predecessores.

Em todo caso, minha conclusão permanece amplamente a mesma: a interação de Estesícoro com os poemas homéricos é algo novo em nossa visão da história literária do mundo grego arcaico. Como eu disse no início deste artigo, recentemente ficamos de novo familiarizados com uma arte allusiva altamente evoluída entre Homero e seus predecessores, gregos e não-gregos, para não falar daquela entre Homero e seus sucessores. Mas a falta de uma sofisticação tão completamente desenvolvida nas interações que examinamos nesta manhã depõe contra isso. Interação textual no período arcaico é uma história de evolução, não de revolução, e os desenvolvimentos de Estesícoro marcam um estágio absolutamente axial na narrativa. ${ }^{102^{*}}$

\section{REFERÊNCIAS}

ADKINS, A. Poetic Craft in the Early Greek Elegists. Chicago: Chicago University Press, 1985. ARRIGHETTI, G. Stesicoro e il suo pubblico. Materiali e discussioni per l'analisi dei testi classici, v. 32, p. 9-30, 1994.

BARRON, J. P. Ibycus: to Polycrates. Bulletin to the Institute of Classical Studies, v. 16, p. 119-149, 1969.

BIRD, G. D. Multitextuality in the Homeric Iliad: the Witness of the Ptolemaic Papyri. Washington DC: Center for Hellenic Studies, 2010.

BLONDELL, R. 'Refractions of Homer's Helen in Archaic Lyric'. American Journal of Philology, v. 131, p. 349-391, 2010.

BOWIE, E. The Trojan War's reception in early Greek lyric, iambic and elegiac poetry. In: Foxhall, L.; Gehrke, H.-J.; Luraghi, N. (ed.). Intentional history: spinning time in ancient Greece. Stuttgart: Franz Steiner, 2010, p. 57-88.

BRASWELL, B. K. Mythological innovation in Homer. Classical Quarterly, v. 21, p. 16-26, 1971.

BURGESS, J. Beyond neoanalysis: problems with the vengeance theory. American Journal of Philology, v. 118, p. 1-19, 1997.

102* $\mathrm{O}$ tradutor agradece à Tatiana Ribeiro e ao Teodoro Rennó Assunção por suas valiosas sugestões e cuidadosa revisão. 
BURGESS, J. The tradition of the Trojan war in Homer and the Epic Cycle. Baltimore: Johns Hopkins University Press, 2001.

BURKERT, W. The Making of Homer in the sixth century BC: rhapsodes versus Stesichorus. In: Bowersock, G.; Burkert, W.; Putnam, M. (ed.). Papers on the Amasis painter and his world. Malibu: J. P. Getty Museum, 1987, p. 43-62.

CALAME, C. Les choeurs de jeunes filles en Grèce archaïque. Rome: Edizioni dell'Ateneo \& Bizzarri, 1977. $2 \mathrm{v}$.

CALAME, C. Alcman. Rome: Edizioni dell'Ateneo \& Bizzarri, 1983.

COOK, R. M. Art and Epic in archaic Greece. Bulletin Antieke Beschaving, v. 58, p. 1-10, 1983.

CURRIE, B. Homer and the early Epic tradition. In: CLARKE, M.; CURRIE, B.; LYNE, R. O. A. M. (ed.). Epic Interactions: papers in honour of Jasper Griffin. Oxford: Oxford University Press, 2001, p. 1-46.

CURTIS, P. Stesichorus' Geryoneis. Leiden: J. Brill, 2011.

DAVIES, M.; FINGLASS, P. J. F. Stesichorus: the poems. Cambridge Classical Texts and Commentaries, 54. Cambridge: Cambridge University Press, 2014.

DAVISON, J. A. Quotations and allusions in early Greek literature. Eranos, v. 53, p. 123-140, 1955. [Reimpressão de: . From Archilochus to Pindar. Papers on Greek literature of the archaic period. London: Macmillan, 1968.]

FEHLING, D. Die Wiederholungsfiguren und ibr Gebrauch bei den Griechen vor Gorgias. Berlin: Walter de Gruyter, 1969.

FERRARI, G. Alcman and the cosmos of Sparta. Chicago: University of Chicago Press, 2008.

FINGLASS, P. J.; KELLY, A. (ed.). Stesichorus in context. Cambridge: Cambridge University Press, 2015.

FORD, A. The inland ship: problems in the performance and reception of Homeric Epic. In: BAKKER, E.; KAHANE, A. (ed.). Written voices, spoken signs: tradition, performance and the epic text. Washington: Center for Hellenic Studies, 1997, p. 83-109.

FOWLER, R. L. The nature of early Greek lyric. Preliminary studies. Toronto: University of Toronto Press, 1987.

GARVIE, A. F. Aeschylus Choephori. Oxford: Oxford University Press, 1986.

GRAZIOSI, B.; HAUBOLD, J. Greek lyric and Greek literary history. In: BUDELMANN, F. (ed.). The Cambridge Companion to Lyric. Cambridge: Cambrigde University Press, 2009, p. 95-113.

GRIFFIN, J. Homer. Iliad IX. Oxford: Oxford University Press, 2009.

HIGBIE, C. Heroes’ names, Homeric identities. New York: Garland, 1995. 
HINGE, G. Die Sprache Alkmans: Textgeschichte und Sprachgeschicbte. Wiesbaden: Reichert, 2006. HUTCHINSON, G. Greek byric poetry. Oxford: Oxford University Press, 2001.

JENSEN, M. S. The Homeric question and the oral-formulaic theory. Copenhagen: Tusculanum Press, 1980.

KAHNEMAN, D. Thinking fast and slow. London: Farrar, Straus and Giroux, 2011.

von KAMPTZ, H. Homerische Personennamen: sprachwissenschaftliche und historische Klassifikation. Göttingen: Vandenhoek und Ruprecht, 1982.

KELLY, A. Stesikhoros and Helen. Museum Helveticum, v. 64, p. 1-21, 2006.

KELLY, A. A referential commentary and lexicon to Homer, Iliad VIII. Oxford: Oxford University Press, 2007.

KELLY, A. Tradição na épica grega arcaica. Letras Clássicas, v. 14, p. 3-20, 2010.

KELLY, A. The mourning of Thetis: 'allusion' and the future in the Iliad. In: MONTANARI, F.; RENGAKOS, A.; TSAGALIS, C. (ed.). Homeric Contexts: neoanalysis and the interpretation of oralpoetry. Berlin: Walter de Gruyter, 2012, p. 211-256.

KIVILO, M. Early Greek poets' lives. The Shaping of the Tradition. Leiden: J. Brill, 2010.

LANE FOX, R. Travelling heroes: Greeks and their myths in the epic age of Homer. London: Penguin, 2008.

LATACZ, J.; NÜNLIST, J.; STOEVESANDT, M. Homers Ilias Gesamtkommentar. Band I: Erster Gesang; Faæ. 2 Kommentar. München, Leipzig: K. G. Saur, 2000.

LIBERMAN, G. Alcée. Fragments. Paris: Belles Lettres, 1999.2 v.

LIGHTFOOT, J. L. Hellenistic collection. Cambridge MA: Harvard University Press, 2009.

LORD, A. B. The Singer of Tales. Cambridge MA: Harvard University Press, 1960.

LOWENSTAM, S. Talking vases: the relationship between the Homeric poems and archaic representations of epic myth. Transactions of the American Philological Association, v. 127, p. 21-76, 1997.

LYNE, R. O. A. M. The Iliad, Gilgamesh and neoanalysis. In: MONTANARI, F.; RENGAKOS, A.; TSAGALIS, C. (ed.). Homeric Contexts: neoanalysis and the interpretation of oral poetry. Berlin: Walter de Gruyter, 2012, p. 543-580.

MAINGON, A. Stesichorus and the epic tradition. PhD thesis, University of British Columbia, 1978.

MAINGON, A. Epic convention in Stesichorus' Geryoneis. SLG S 15. Phoenix, v. 34, p. 99107, 1980. 
MAINGON, A. Form and content in the Lille Stesichorus. Quaderni Urbinati di Cultura Classica, v. 31, p. 31-56, 1989.

MEYERHOFF, D. Traditioneller Stoff und individuelle Gestaltung. Untersuchungen zu Alkaios und Sappho. Hildesheim: Olms-Weidmann, 1984.

NAGY, G. Poetry as performance: Homer and beyond. Cambridge: Cambridge University Press, 1996.

OBBINK, D. A new Archilochus poem. Zeitschrif für Papyrusforschung und Epigraphik, v. 156, p. 1-9, 2006.

PAGE, D. L. Sappho and Alcaeus: an introduction to the study of ancient Lesbian Poetry. Oxford: Oxford University Press, 1955.

POWELL, J. U. Collectanea Alexandrina. Oxford: Oxford University Press, 1925.

RANK, L. P. Etymologiseering en verwante verschijnselen bij Homerus. Assen: Van Gorcum, 1951.

REECE, S. Homeric influence in Stesichorus’ Nostoi. BASP 25, 1988, p. 1-8.

RICHARDSON, N. J. The Iliad: a Commentary. Volume VI: Books 21 4. Cambridge: Cambridge Uiversity Press, 1993.

RISCH, E. Wortbildung der homerischen Sprache. Berlin: Walter de Gruyter, 1974.

RISSMAN, L. Love as war: Homeric allusions in the poetry of Sappho. Königstein: Hain, 1984.

ROCHA, R. Estesícoro entre épica e drama. Phaos, v. 9, p. 65-79, 2009.

ROSENMEYER, P. A. Her master's voice: Sappho's dialogue with Homer. MD, v. 39, p. 123-149, 1997.

RÖSLER, W. Dichter und Gruppe: eine Untersuchung zu den Bedingungen und zur historischen Funktion fruber griechischer Lyrik am Beispiel Alkaios. München: Fink, 1980.

ROZOKOSKI, A. Stesichorus, Geryoneis S 11 SLG: the Dilemma of Geryon. Wiener Studien, v. 121, p. 67-69, 2008.

RUSSO, J. Stesichorus, Homer, and the forms of early Greek epic. In: KAZAZIS, J. N.; RENGAKOS, A. (ed.). Euphrosyne: studies in ancient epic and its legacy in honour of Dimitris $N$. Maronitis. Stuttgart: F. Steiner, 1999, p. 339-348.

SCHADEWALDT, W. Einblick in die Erfindung der Ilias: Ilias und Memnonis. In:

Von Homers Welt und Werk. 4. ed. Stuttgart: Koehler, 1965, p. 155-202.

SCHEIN, S. The Horses of Achilles in Book 17 of the Iliad. In: REICHEL, M.; RENGAKOS, A. (ed.). Epea pteroenta. Beiträge zur Homerforschung. Festschrift für Wolfgang Kullmann zum 75. Geburtstag. Stuttgart: Franz Steiner, 2002, p. 193-206.

SCHRENK, L. Sappho Fr. 44 and the Iliad, Hermes, v. 122, p. 144-150, 1994. 
SLATKIN, L. The Power of Thetis. Berkeley: University of California Press, 1991.

SNODGRASS, A. Homer and the Artists. Cambridge: Cambridge University Press, 1998.

SPELMAN, H. Alcaeus 140. Classical Philology, v. 110, p. 353-360, 2015.

STEINER, D. Nautical Matters: Hesiod's Nautilia and Ibycus fragment 282 PMG. Classical Philology, v. 100, p. 347-355, 2005.

STEINRÜCK, M. Homer bei Sappho?. Mnemosyne, v. 52, p. 139-149, 1999.

SUÁREZ DE LA TORRE, E. S. 'Ya vienen los novios': una lectura socioantropológica del fragmento 44 V. de Safo. Faventia, v. 30, p. 143-160, 2008.

TSITSIBAKOU-VASALOS, E. Stesichorus' Geryoneis, SLG 15 I-II. E 1 HNIKA, v. 41, p. 7-31, 1986.

TSITSIBAKOU-VASALOS, E. SLG 11 5-26: The dilemma of Geryon. EA HNIKA, v. 42, p. 245-261, 1991-1992.

VAGNONE, G. Aspetti formulari in Stesicoro, 'Pap. Lille' 76 a b c: il desiderio di morte. Quaderni Urbinati di Cultura Classica, v. 12, p. 35-42, 1982.

WATHELET, P. Dictionnaire des Troyens de l'Iliade. Liège: Université de Liège, 1988. 3 v.

WEST, M. L. The Rise of the Greek Epic. Journal of Hellenic Studies, v. 108, p. 151-172, 1988. Reimpresso em WEST, 2011.

WEST, M. L. The date of the Iliad. Museum Helveticum, v. 52, p. 203-219, 1995.

WEST, M. L. The East Face of Helicon: West Asiatic elements in Greek poetry and Myth. Oxford: Oxford University Press, 1997.

WEST, M. L. The View from Lesbos. In: REICHEL, M.; RENGAKOS, A. (ed.). Epea pteroenta. Beiträge zur Homerforscbung. Festscbrift für Wolfgang Kullmann zum 75. Geburtstag. Stuttgart: Franz Steiner, 2002, p. 207-219.

WEST, M. L. Indo-European poetry and myth. Oxford: Oxford University Press, 2007.

WEST, M. L. Hellenica. Selected papers on Greek literature and thought. Volume I: Epic. Oxford: Oxford University Press, 2011.

WILKINSON, C. L. The lyric of Ibycus. Berlin: Walter de Gruyter, 2013.

WILLCOCK, M. M. Mythological Paradeigma in the Iliad. Classical Quarterly, v. 14, p. 141 154, 1964. 